Review

\title{
Review on environmental models in the food chain - Current status and future perspectives
}

\author{
Ilija Djekic a, *, Neus Sanjuán ${ }^{\mathrm{b}}$, Gabriela Clemente ${ }^{\mathrm{b}}$, Anet Režek Jambrak ${ }^{\mathrm{c}}$, \\ Aleksandra Djukić-Vuković ${ }^{\mathrm{d}}$, Urška Vrabič Brodnjak ${ }^{\mathrm{e}}$, Eugen Pop ${ }^{\mathrm{f}}$, Rallou Thomopoulos ${ }^{\mathrm{g}}$, \\ Alberto Tonda ${ }^{\text {h }}$
}

${ }^{a}$ Department of Food Safety and Quality Management, University of Belgrade - Faculty of Agriculture, Belgrade, Serbia

${ }^{\mathrm{b}}$ ASPA Group (Analysis and Simulation of Agro-Food Processes), Food Technology Department, Universitat Politècnica de València, Spain

${ }^{c}$ Department of Food Engineering, Faculty of Food Technology and Biotechnology, University of Zagreb, Croatia

${ }^{\mathrm{d}}$ Department of Biochemical Engineering and Biotechnology, Faculty of Technology and Metallurgy, University of Belgrade, Serbia

e Faculty of Natural Sciences and Engineering, University of Ljubljana, Slovenia

${ }^{\mathrm{f}}$ SC IPA SA, Bucharest, Romania

${ }^{\mathrm{g}}$ Institut National de la Recherche Agronomique / Institut national de recherche en informatique et en automatique, Montpellier, France

${ }^{\mathrm{h}}$ Institut National de la Recherche Agronomique, Thiverval-Grignon, France

\section{A R T I C L E I N F O}

\section{Article history:}

Available online 5 December 2017

\section{Keywords:}

Environment

Food systems

Food processes

Models

Interaction

\begin{abstract}
A B S T R A C T
Diversity of food systems and their interaction with the environment has become a research topic for many years. Scientists use various models to explain environmental issues of food systems. This paper gives an overview of main streams in analyzing this topic. A literature review was performed by analyzing published scientific papers on environmental impacts in the food chain. The selection criteria were focused on different environmental approaches applied in the food chain and on the perspectives of future research.

This review shows that on the one side there are generic environmental models developed by environmental scientists and as such applied on food. On the other side, there are models developed by food scientists in order to analyze food-environmental interactions. The environmental research in food industry can be categorized as product, process or system oriented. This study confirmed that the focus of product based approach is mainly performed through life-cycle assessments. The process based approach focuses on food processes such as heat transfer, cleaning and sanitation and various approaches in food waste management. Environmental systems in the food chain were the least investigated stream analyzing levels of environmental practices in place.

Future research perspectives are the emerging challenges related to environmental impacts of novel food processing technologies, innovative food packaging and changes in diets and food consumption in connection with climate and environmental changes.
\end{abstract}

() 2017 Elsevier Ltd. All rights reserved.

\section{Contents}

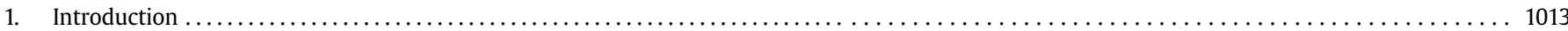

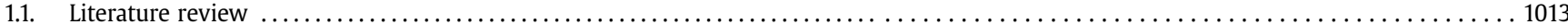

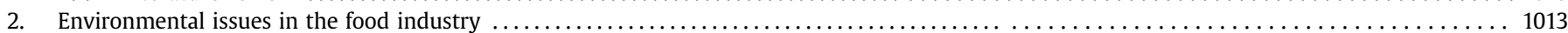

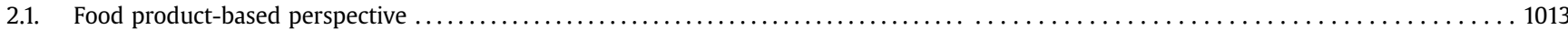

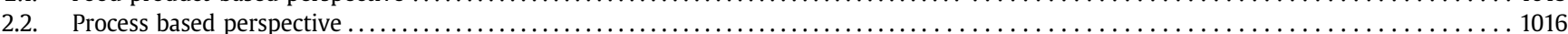

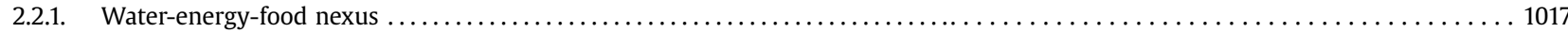

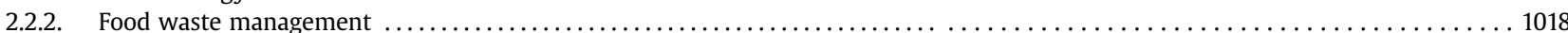

\footnotetext{
* Corresponding author.Department of Food Safety and Quality Management, Faculty of Agriculture, University of Belgrade, Nemanjina 6, 11080 Belgrade, Serbia. E-mail address: idjekic@agrif.bg.ac.rs (I. Djekic).
} 


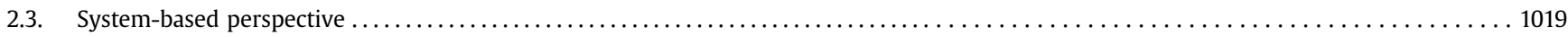

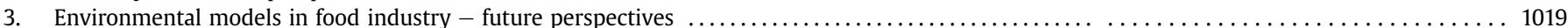

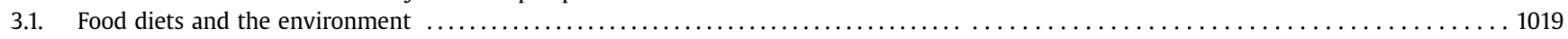

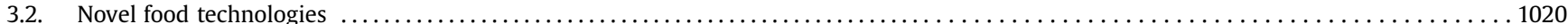

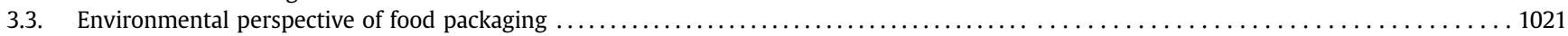

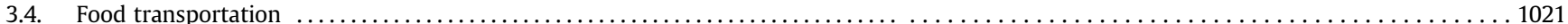

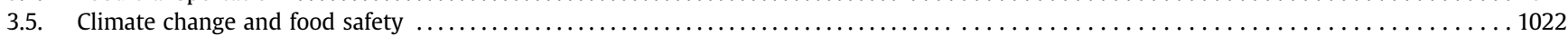

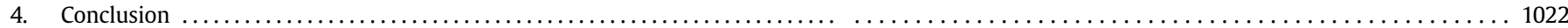

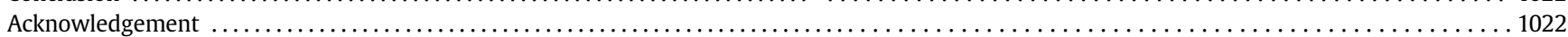

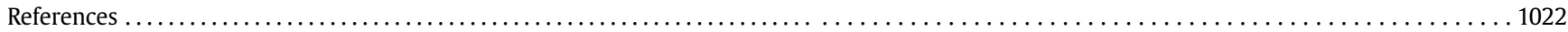

\section{Introduction}

Describing the complex links between food and environment is a relatively recent research field, starting from the so-called "ecology of food", a university discipline taught in Germany since 1987 (Leitzmann, 2002; Schneider and Hoffmann, 2011). In other European countries, this research domain is integrated in environmental science, agricultural science or in "agroecology" (Wezel et al., 2009). However the "grey" literature started in the 1970s (Moore-Lappé, 1971), and one of the very first scientific publications from the 1980s (Gussow and Clancy, 1986) was encouraged by the Stockholm environment summit of the United Nations in 1972. Since then, environmental assessment methods have been refined and applied to various food products, in order to help producers and industries improve food production from an environmental point of view.

Recent European consumption studies show that food production is responsible for up to $50 \%$ of environmental impacts (Notarnicola et al., 2012; Roy et al., 2012). The environmental regulations directly or indirectly covering the environmental impact in food process design have increased in the last years (Romdhana et al., 2016). As a consequence of this, the development of sustainable strategies for food supply chains is in gaining importance and the number of companies involved in this subject is increasing each year. There are a lot of methods and models, specifically developed and adapted to the planning, processing and control from farm to retail and household. The focus is not only on reducing costs, but also to achieve sustainability and environmental preservation (Akkerman et al., 2010; Battini et al., 2014; Manzini and Accorsi, 2013).

The objective of this review paper is to present the main research streams for analyzing food chain's environmental performance and to identify future research perspectives. Section 2 performs an in-depth survey of current state of progress, according to the existing environmental research perspectives. Section 3 is devoted to future perspectives covering the emerging challenges related to environmental impacts of novel processing technologies, innovative food packaging and changes in diets and food consumption in connection with climate and environmental changes. Concluding remarks are given in Section 4.

\subsection{Literature review}

Mathematical models describing food processes are very useful in engineering design and optimization. They allow evaluation of different food processing alternatives (variety of raw material, optimization of processing conditions, packaging ...) in order to improve decision making. Thus this is a very interesting and useful research area, which is confirmed by the increase in the number of publications in this subject in the last years. A literature review was performed by analyzing published scientific papers and the major sources of information were the scholarly databases such as Web of Science, EBSCO, Springer, ScienceDirect and Google Scholar. This research identified relevant articles, both review and research papers, published in the domains of environmental/mathematical models (environmental models, mathematical models, life cycle assessment (LCA), simplified LCA, specific impacts i.e. energy, water, waste water, etc.) and approaches in the food chain (food, food chain, food processing, specific types of food i.e. meat, dairy, etc.). There were no geographical restrictions applied. The selection criteria chosen to identify the relevant articles were related to the objectives of this paper: (1) focus on environmental models applied in the food chain; (2) focus on the potential for future research.

Within the above mentioned databases, 19,385 publications between 1991 and 2016 were found using model, food and process as keywords in the Web of Science. Out of this number, 5341 were included in the research area Food Science and Technology and 2595 in the research area Environmental Sciences and Ecology (Fig. 1), showing an increased trend during the considered period. The majority of published research/studies related to the environmental impacts of the food industry were focused on the following: (i) product-based research, mainly through life cycle assessment (LCA); (ii) process-based research focused on specific food processes and their interaction with the environment; (iii) companybased research, based on various environmental management tools. The perspective of such research was from an environmental point of view or from a food science point of view.

When keywords related to environmental impacts were added to the previous ones (food, process and model) in the search engine of the Web of Science database (research area Environmental Sciences Ecology) the number publications in the period 1991-2016 decreases (Table 1). Another important question was to define the food sectors related with the publications. Table 2 presents, the main food sectors found in the Web of Science database using model, food, process and environment as keywords and considering only the research area Environmental Science and Ecology. As it can be observed, the food sectors with the highest number of publications in modeling and environment are fish and seafood, distribution and feed, while the number of publications on the other sectors is substantially lower.

The outcome of articles assessing the environmental impacts of the food chain depends not only on the systems studied, but also on the environmental methodologies and evaluation methods used (Reckmann et al., 2012). In concurrence with a review of environmental impacts in the meat chain (Djekic and Tomasevic, 2016), three environmental research perspectives recognized in the food chain are food products, the manufacturing food processes and the environmental systems in which the food companies operate, Fig. 2.

\section{Environmental issues in the food industry}

\subsection{Food product-based perspective}

Life Cycle Assessment is the main methodology applied to assess the environmental impact of products and it has been increasingly 


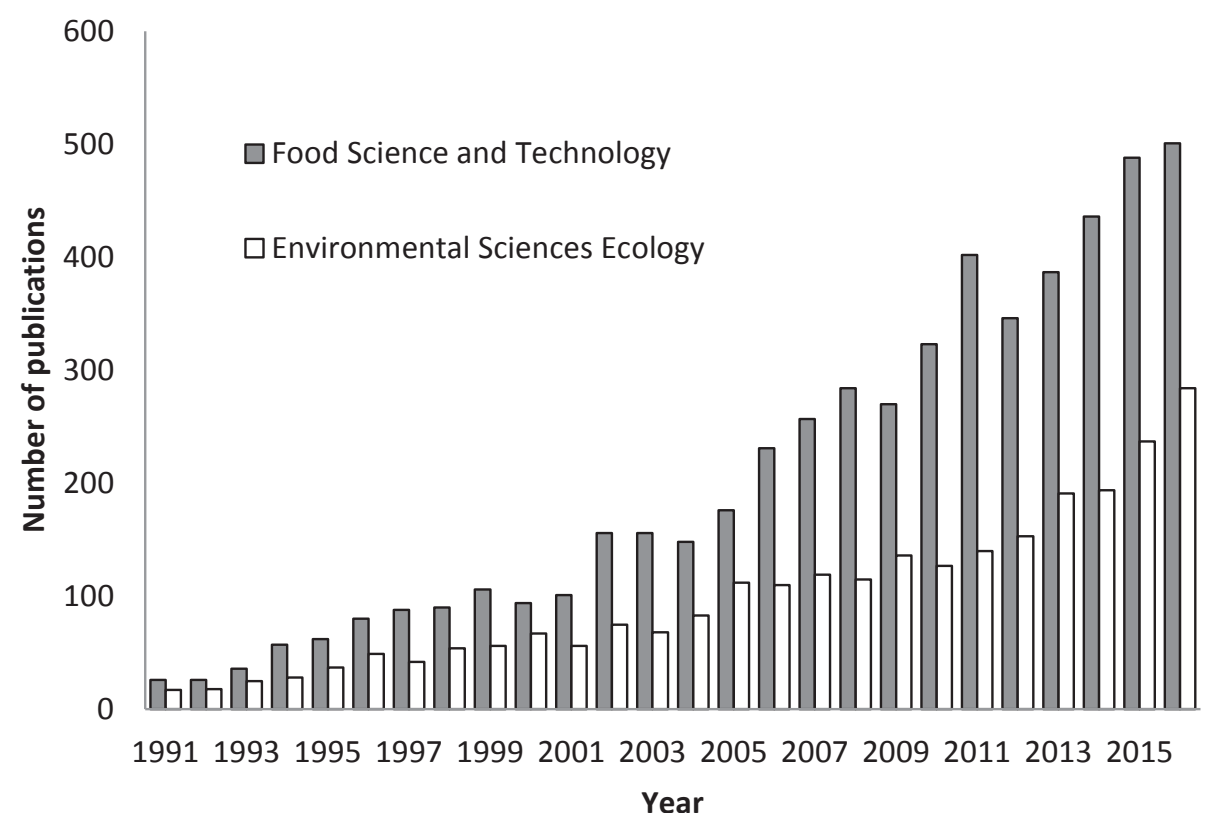

Fig. 1. Number of publications about modeling, food and process.

applied to products of the agri-food sector (Arzoumanidis et al., 2017; Jacquemin et al., 2012; Nucci et al., 2014). It is a scientific method that includes the following steps outlined in ISO 14040: mapping the process, setting the scope and boundaries, collecting data, calculating, evaluating and interpreting the results with the aim to propose environmental improvements (ISO, 2006).

Food systems are sufficiently different from other product systems, mainly because of the agricultural stage, which implies a close interlink between nature and the technosphere. Consequently, the application of LCA to these systems introduces new methodological issues (Milà i Canals et al., 2006; Perrin et al., 2014). The first LCAs on food products began in 1990s and in the last 16 years it has been commonly applied to this sector covering an extensive range of foods, mostly meat, dairy, fish, fruit and vegetables as well as wine and other beverages.

Since the meat chain is widely recognized as one of the main polluters in the food sector, several reviews have been carried out on the application of LCA to this sector (de Vries and de Boer, 2010; De Vries et al., 2015; Djekic and Tomasevic, 2016; McAuliffe et al., 2016). Although vegetable products are generally considered to have a lower environmental impact potential than other foods in western diets, many studies agree that field production stage is one of the greatest contributors to environmental pollution. In this sense, Bessou et al. (2013), Perrin et al. (2014) and Cerutti et al. (2014) reviewed different LCA aspects of the agricultural stage of vegetables. Fish products have been tackled in the studies of Henriksson et al. (2012) for aquaculture, and Pelletier et al. (2007) for seafood. Among drinks, the environmental impact of wine production in different countries and origin appellations has been assessed and therefore some reviews focused on the LCA and carbon footprint of this product have been carried out (Rinaldi et al., 2016; Rugani et al., 2013).

Mapping the process and setting the scope and boundaries are important in order to clarify parts of the food chain analyzed from the "farm to fork" perspective. Most of the LCAs on food products apply "cradle-to-gate" systems boundaries, that is, they are mainly focused on the farm level. Nevertheless, other system boundaries are applied in the literature, such as "cradle-to-market" in which the distribution and commercialization phase is also involved, or the so called "cradle-to-use" in which impacts from the consumer phase are assessed, although these are scarce. An important point when defining the system boundaries of agricultural systems is whether the whole plant cycle must be included or not. In the case of perennial crops, as Bessou et al. (2013) and Cerutti et al. (2014) point out, most published LCAs are based on one productive year. But perennial systems, unlike annual crops, involve plants with very variable duration. As regards to the temporal representativeness, most of the reviewed studies are focused on one farming season, and only few studies cover the temporal variability of perennial crops (Bessou et al., 2016; Vázquez-Rowe et al., 2012).

A generic model of the food product's life cycle system boundaries is presented in Fig. 3. The system boundaries in animal origin food chain cover at least four subsystems (Djekic et al., 2014a; Djekic and Tomasevic, 2016). Subsystem 1 - 'Farm' includes all livestock activities which take place in a farm, including production of raw milk. It may include contribution of feed production and waste/manure management. When such subsystems are covered within a LCA, they enable comparing different methods of livestock

Table 1

Number of publications (database Web of Science, research area Environmental Sciences (Ecology) about food, process and model and environmental issues between 1991 and 2016.

\begin{tabular}{|c|c|c|c|c|}
\hline Keyword & Food & Process & System & $\begin{array}{l}\text { Number } \\
\text { of publications }\end{array}$ \\
\hline Environment & $\bullet$ & - & $\bullet$ & 500 \\
\hline Environmental impact & $\bullet$ & $\bullet$ & $\bullet$ & 262 \\
\hline Waste water & - & $\bullet$ & • & 126 \\
\hline Water consumption & - & - & 0 & 85 \\
\hline Life Cycle Assessment & $\bullet$ & - & $\bigcirc$ & 71 \\
\hline Energy consumption & • & $\bullet$ & • & 70 \\
\hline Global warming & $\bullet$ & - & $\bigcirc$ & 58 \\
\hline Air emissions & - & $\bullet$ & $\bigcirc$ & 40 \\
\hline Cleaner production & - & $\bullet$ & 0 & 16 \\
\hline Fuel consumption & - & $\bullet$ & ○ & 14 \\
\hline
\end{tabular}

Legend: "Food", "Process" and "System" refer to the three environmental research perspectives in the food chain. Symbols show the main focus of publications: strong focus ( $70-100 \%$ of publications); 0 moderate focus (30-70\% of publications); weak focus $(0-30 \%$ of publications). 
production such as organic vs. conventional or indoor vs. outdoor animal husbandry (McAuliffe et al., 2016). Activities such as reception of live animals, livestock handling, animal welfare, slaughtering and chilling (Djekic et al., 2015) or activities like collecting and distributing raw milk in the dairy sector (Djekic et al., 2014a) are either a part of subsystem 1 or 2 . Subsystem 2 - 'Processing plant' in meat sector covers all activities from reception of carcasses, thermal processing, waste handling up to the storage of final meat products (Djekic et al., 2015). In the dairy sector, this subsystem covers activities from receipt of raw milk to production of dairy products (Djekic et al., 2014a).

In wine production, we observe similar subsystems as vineyard planting and viticulture and grape growing contribute to subsystem 1 while wine making is within subsystem 2 (Rugani et al., 2013). In fruit production the nursery phase and orchard establishment may be considered as subsystem 1 (Cerutti et al., 2014). Further fruit processing to various food products is within subsystem 2.

Subsystem 3 - 'Retail' comprises of activities that take place where food products are sold. These sales spots may be either in supermarkets and grocery shops or may be in specialized shops. Subsystem 4 - 'Household use' comprises of refrigeration of food (Coulomb, 2008), food preparation and cooking (Xu et al., 2015).

The functional unit (FU) is a key aspect when performing an LCA, as it is the unit to which the results are expressed and a basis for comparisons. The FU must take into account the function of the systems and a proper choice of the FU is of central importance because different functional units can lead to different results for the same product systems (Djekic and Tomasevic, 2016). Most of the LCA studies on food use a FU quantified by physical units, mainly mass or volume based for drinks whereas area (e.g. ha) is also widely use in agricultural LCAs. However, we must not forget that the main function of food is providing nutrients. Heller et al. (2013) reviewed different kinds of FUs based on this nutritional function, and as stated by the authors, no consistent solution emerged.

The economic value is another criteria taken into account to define the FU in food LCAs (e.g. (Dutilh and Kramer, 2000; Mouron et al., 2006a). According to Dutilh and Kramer (2000) economic value captures the "emotional value" of food. van der Werf and Salou (2015) recommend this kind of FU because it considers product quality through the product's price. Ponsioen and Van Der Werf (2017) argue that this FU reflects the way a consumer values the different functionalities of food and takes into account the possible rebound effects of spending saved money on other environmentally damaging activities into account. Summarizing, although mass-based FU is by far the most dominant FU in LCA of food products, using several other FUs allows the multifunctionality of foods to be captured (Mouron et al., 2006b; van der Werf and Salou, 2015).

Many LCA studies agree that life cycle inventory (LCI) is the most time consuming step since it implies data collection from the subsystems, aggregation and validation. Collecting data from the subsystems is crucial for LCA, since the uncertainty of these data may cause imprecise calculation of various environmental indicators (Djekic, 2015). Both primary and secondary data sources are used to carry out a LCI. Primary sources are mainly used for the foreground system, the core of the studied system. Therefore representativeness of the primary data is crucial. The type and sources for the foreground data and the scale can vary from local to regional or even global (Avadí et al., 2016; Bartl et al., 2012) and the data source cover from surveys to one or small samples of representative producers (Vázquez-Rowe et al., 2014) to large ones (Ribal et al., 2016b). Other studies model the foreground system based on representative scenarios built from surveys and other sources as
Table 2

Number of publications (database Web of Science, research area Environmental Sciences (Ecology) about food sectors related to food, process and model and environmental issues between 1991 and 2016.

\begin{tabular}{ll}
\hline Food sector & Number of publications \\
\hline Fish and seafood & 89 \\
Distribution & 83 \\
Feed & 81 \\
Egg & 19 \\
Oil and fat & 17 \\
Milk and dairy & 15 \\
Cereal and grains & 13 \\
Fruit and vegetables & 10 \\
Meat and poultry & 8 \\
Additive & 6 \\
\hline
\end{tabular}

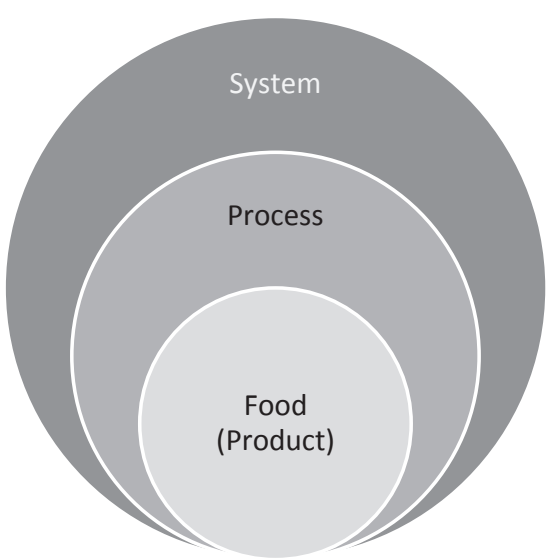

Fig. 2. Environmental research perspectives in the food chain.

statistics or interviews with experts or multivariate statistics tools (Avadí et al., 2016). Ribal et al. (2016b) analyze the variability of the foreground system data and that of the subsequent impacts by using non parametric statistics, specifically by means of a bootstrap technique. Analysis of these inventory data requires calculation of specific environmental impacts defined in the goal and scope of the LCA (McAuliffe et al., 2016). In case of multifunctional systems and for the purpose of conversion from the 'whole of subsystem basis' to a 'functional unit basis', allocation of inputs and outputs is needed (Djekic and Tomasevic, 2016). There are three main allocation methods: economic allocation, physical allocation and system expansions (de Vries and de Boer, 2010).

Several authors have tried to simplify data collection in order to make LCA easier to perform, especially for small and medium-sized enterprises (SMEs) (Arzoumanidis et al., 2014; Hochschorner and Finnveden, 2003; Masoni et al., 2004). Arzoumanidis et al. (2017) presented a simplified LCA model for three different product types such as coffee, lemon juice and olive oil. The presented work has a relevant approach in order to make LCA easier to perform in SMEs, which usually lack resources. They used three simplified LCA tools and made a detailed analysis and proposed solutions for improving the applied tools.

The studies mentioned above are built on the traditional LCA framework, also known as attributional LCA, which calculates the environmental impacts associated with the delivery of a specific amount of product. However, this approach fails when estimating the indirect effects associated with a change in the demand for the same amount of product engendered in the markets by the underlying actions (Vázquez-Rowe et al., 2014). In view of this limitation, a new approach has emerged in the last few years: the 


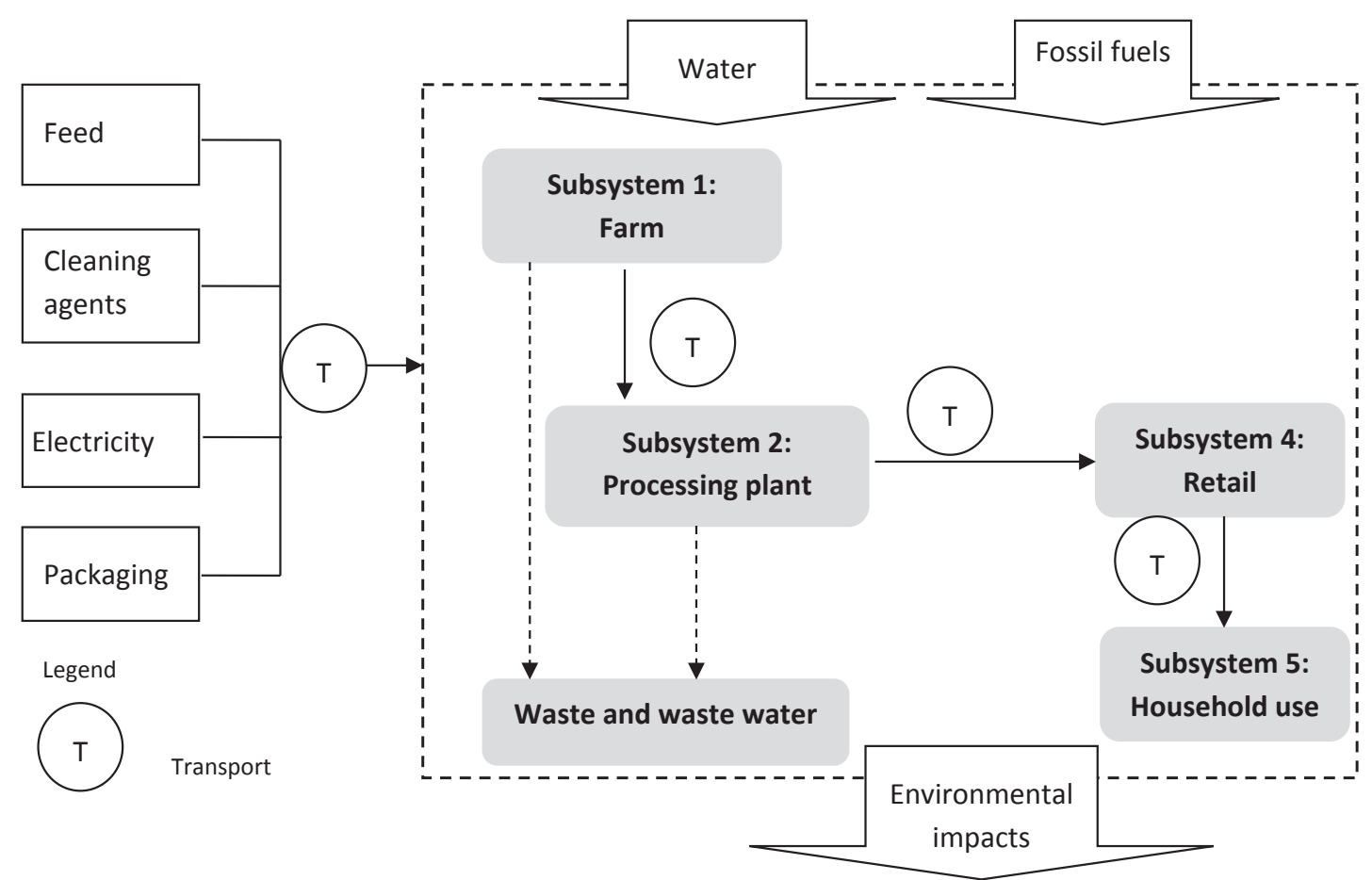

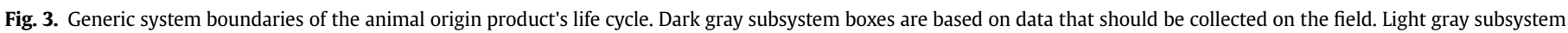
boxes are based on database(s). Adapted from Djekic and Tomasevic (2016).

consequential LCA. The main idea of this is that the assessment includes the consequences of a change affecting the initial product system studied, and which may affect other life cycles non connected by mass or energy flows to the studied system (Dandres et al., 2011). The consequential LCA has been successfully applied in the evaluation of the indirect changes of land use leaded by the cultivation of raw materials for biodiesel production e.g. (Escobar et al., 2017; Schmidt et al., 2015). The consequential approach could also be suitable to elucidate whether the introduction of normative measures to change food consumption (such as taxes to meat consumption) really leads to a decrease of the environmental impact of the whole food chain by assessing.

A literature review of LCA in the food chain has enabled grouping published papers according to the following criteria: types of LCA model, impact focus, subsystems analyzed, product type, and environmental impact. The LCA, simplified LCA or nonLCA models have the objectives to quantify the environmental performances in the whole food product chain. Regarding the approach three main types occur: LCA, variations of LCA and nonLCA models. Depending on the model, the following criteria apply: (i) if the model is generic or specific for food industry; (ii) if it is user friendly/or not; (iii) if it is free/payable; (iv) if it is focused on one environmental impact or several; ( $v$ ) besides environment, if it focuses on some other sustainability dimension (economic, social) (vi) if it requires specific environmental knowledge, etc. As for subsystems, authors divide subsystems at farms, at processing plants, and upon distribution of final product (retail and/or household). Depending on the LCA methodology applied, different environmental impacts are calculated, Fig. 4. The common denominator is the global warming potential due to the importance that this environmental impact has on the society. Nevertheless, other environmental impacts can be evaluated. For example, dairy industry is mainly focused on global warming, potential, acidification potential, eutrophication potential, and ozone layer depletion (Djekic et al., 2014a). In meat industry, global warming potential, acidification and eutrophication potential prevail (Djekic and Tomasevic, 2016) while poultry industry besides these potentials also calculates land use (Skunca et al., 2016). Wine industry covers also resource depletion (Rugani et al., 2013). Except in specific cases like Nucci et al. (2014), the common denominator is the global warming potential.

Motivation of food companies to use LCA and generally apply modeling of environmental impacts of their products, including processing, is increasingly attractive in order to obtain environmental labels for the food they produce. The pressure on ecolabeling brings us to the necessity of creating and using userfriendly LCA models, especially from the perspective of SMEs. Grunert et al. (2014) confirmed that sustainability labels still do not play a major role in consumers' food choices, but future use of these labels will depend on consumers' general concern about sustainability. Recent publication of an environmental labeling standard brings a new dimension in food labels and declarations (ISO, 2016a). Different simplified models and tools for assessment of environmental performance in food companies were developed in order to enable wider and easier application in food companies with limited resources. In this sense further research should include variability in LCA results considering different assessment methods and to introduce more environmental impacts.

\subsection{Process based perspective}

Modeling in food processing has been mostly used in order to optimize the manufacturing process and increase yields and productivities or to simulate energy and mass transfer phenomena in food during processing. Nevertheless, the process optimization can have a significant effect on the environmental performance of food. The processing step, as part of a food supply chain, has been most often studied as a "black box" in LCA of food products due to the lack of data or confidentiality issues (Avadí et al., 2015; Del Borghi et al., 2014). Furthermore, modeling as well as comparison of 
different processing techniques within similar technologies was difficult. Similar constraints are present and important for analyzing novel food processing methods and introduction of new/ improved/modified products. Generic "food processing" model is presented in Fig. 5.

Mathematical models have also been widely used to simulate all aspects of bioenergy in production systems including the growth kinetics of energy crops, conversion processes, production economics, supply logistics and environmental impacts. Those models can provide powerful tools to design a bioenergy system and evaluate its technical feasibility, economics and environmental impacts. In food industry, a combination of process models and reaction kinetics provides advanced computational tools for the design and optimization of various biomass conversion processes.

Thermal processing is among the most often used methods in food industry and it has been examined first in terms of modeling and optimization. For instance Teixeira et al. (1969), studied modelbased computational methods to design and/or optimize thermal processing of food to more recent stochastic and deterministic global optimization methods (Banga et al., 2003). These models were not mainly developed in order to address the environmental impacts of the studied thermal processing method, but because of the significant amount of energy used in this process. LCA was applied for comparison of thermal (conventional pasteurization) and non-thermal processing technologies (microwaves, high hydrostatic pressure, modified atmosphere packaging) and it has shown that emerging technologies are lower in $\mathrm{CO} 2$ production and energy demand as well as in water consumption under the defined conditions of up to 30 days shelf life (Pardo and Zufía, 2012).

\subsubsection{Water-energy-food nexus}

Although in many studies energy and water inputs in processing were optimized or studied separately, water, energy and food (WEF) are inextricably interrelated. This nexus has a significant environmental impact and should be considered together. Effective planning and management of limited WEF resources to meet current and future socioeconomic demands for sustainable development is necessary. Nexus management for WEF security necessitates integrated tools for predictive analysis that are capable of identifying the tradeoffs among various sectors, generating costeffective planning and management strategies and policies. To address these needs, Zhang and Vesselinov (2016) have developed an integrated model. It provides a multi-period socioeconomic model for predicting how to satisfy WEF demands based on model inputs representing productions costs, socioeconomic demands, and environmental controls.

Al-Ansari et al. (2014) integrated WEF systems in one resource model described by a series of sub-systems (food sub-system, water sub-system, energy sub-system). It was shown that the food subsystem produces the largest emissions, followed by energy and water. Garcia and You (2016) identify engineering opportunities to appropriately model and optimize the WEF. Various uncertainties appear at all scales of the WEF and this issue must be considered.

A typical food processing step is cleaning and sanitation, related to the high water consumption and production of significant amounts of wastewater. It is a prerequisite program outlined in international food safety standards that intends to ensure good hygiene practice (CAC, 2003; ISO, 2005). It prevents the development of biofilms and reduces the possibility of food contamination (Campdepadrós et al., 2012). A typical cleaning method is "cleaning in place (CIP)" that cleans solely by circulating and/or flowing chemicals and water rinses by mechanical means onto and over surfaced to be cleaned (BSI, 2008). CIP process requires large amounts of water, chemicals and energy. Energy usage varies, depending on the process and importance of optimization is

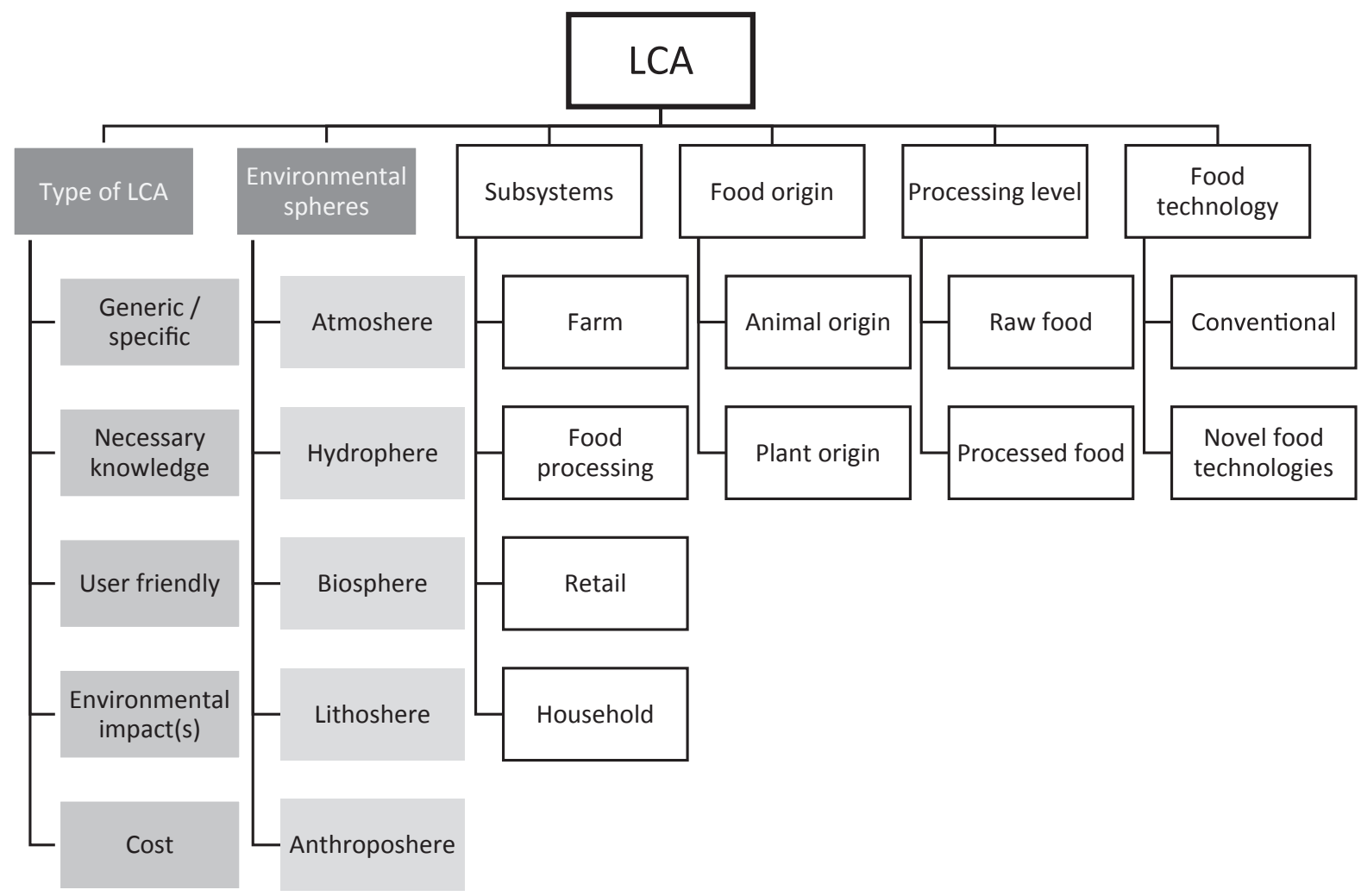

Fig. 4. Generic overview of LCA types present in the food chain. Dark gray boxes are generic for any type of industry. Legend: LCA - life cycle assessment. 


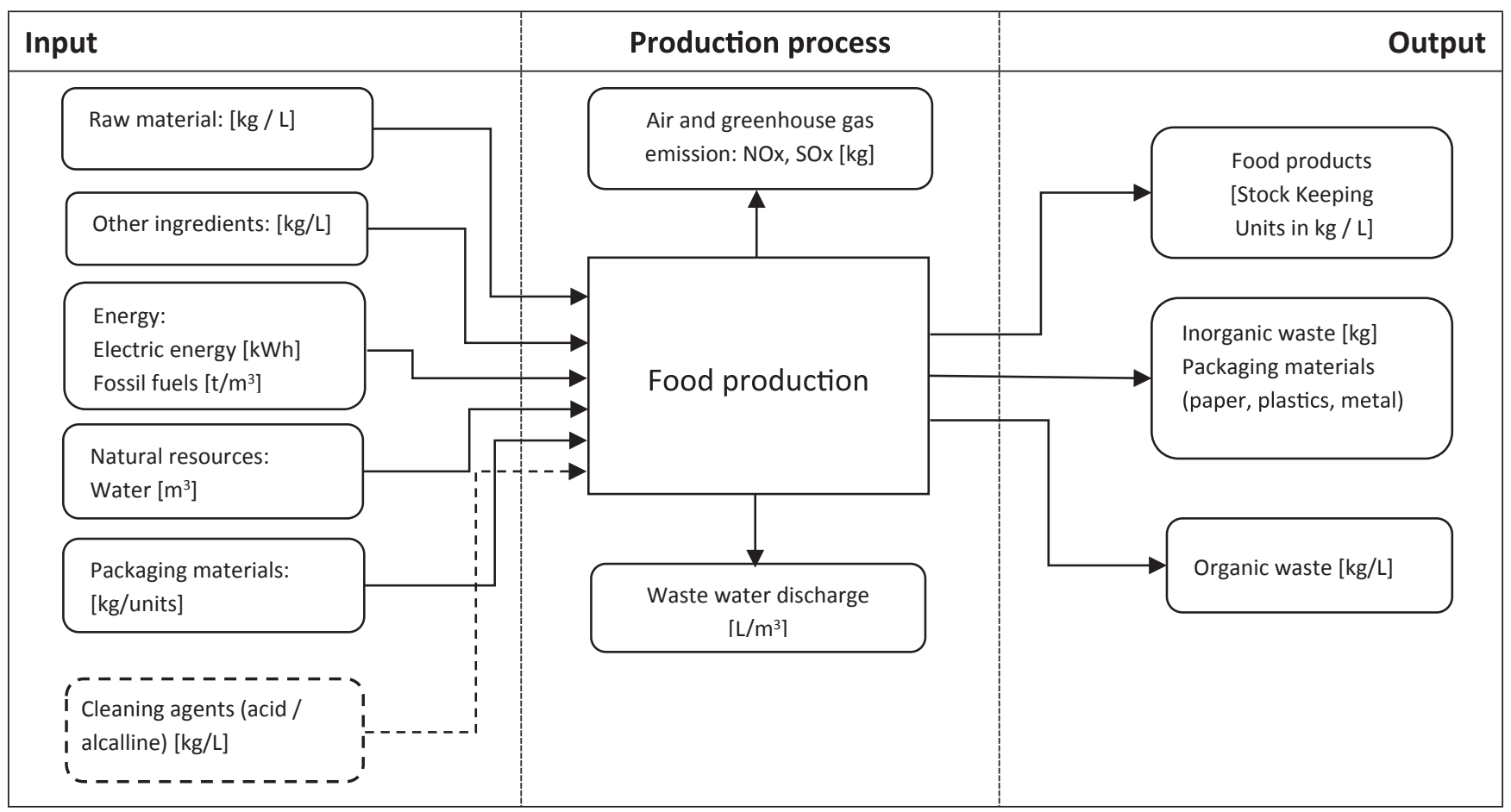

Fig. 5. Generic model of food production. Adapted from Djekic and Tomasevic (2016).

considered crucial. It is estimated that milk plants are likely to use $13 \%$ of its energy on CIP, whereas a powered milk, cheese and whey process will use $9 \%$ of its energy on CIP (Prasad et al., 2005). In some plants, combined efforts to decrease water consumption, wastewater production and energy savings through optimization were proposed. Installment of heat exchangers on processing lines, introduction of a system to optimize accurate chemical and water usage during cleaning, optimization of CIP procedures in general and other strategies for improvement of eco-efficiency are means of improvements (Pagan and Prasad, 2007).

Other employed strategies included generation of estimation tools for the energy demand of a range of food process unit operations, as developed by Sanjuán et al. (2014). In a similar manner, Walker et al. (2017) provide methods to determine water use in order to calculate the water required for unit operation of food processing. These tools were tested through case studies and the measured energy and water results proved its accuracy.

\subsubsection{Food waste management}

Different types of solid waste and wastewater generated throughout the food chain contribute significantly to the environmental footprint of food industry. Food waste, food loss and other terms used to address remains not suitable for consumption as food are used inconsistently in the literature as also observed by Cerutti et al. (2014). In crops, vegetables and fruit processing, major food losses are related to low productivities, inefficiency in processing, contamination, damage of products during packaging, while there are also unavoidable amounts of products which have to be discarded during processing (bones, seeds, skin, etc.). Depending of the type of food loss (avoidable or unavoidable) and the amount generated in food processing, different scenarios that variously affect the environmental impact of the food chain were proposed by Corrado et al. (2017).

Utilization of by-products and process modifications to prevent excessive amount of food waste along the entire food chain were proposed and studied by different researchers (Chen et al., 2017; Mourad, 2016). Some proposed strategies are based on revalorization through extraction of high-value ingredients from waste generated during fruit and vegetables processing (Baiano, 2014; Hernández-Carranza et al., 2016). Remains from other links of the food chain are used mostly as substrates for the production of platform chemicals and biofuels, like lactic acid and other low volatile organic acids (Dahiya et al., 2015; Djukić-Vuković et al., 2015; RedCorn and Engelberth, 2016). Other possibilities for utilization of food waste is for feed (San Martin et al., 2016) providing revalorization of nutrients still present in food waste or anaerobic digestion, composting, incineration and landfill as the most abundant strategies for organic waste in general. The influence of process parameters and pretreatment of food waste on environmental indicators was also studied. The biogas production, volatile solids' degradation and chemical oxygen demand degradation during anaerobic digestion of food waste were examined depending on the pretreatment as the most prominent parameter that contributes towards output responses followed by $\mathrm{pH}$, solids' concentration, temperature and carbon to nitrogen ratio (Deepanraj et al., 2017).

Efforts to address sustainability of these strategies as well as to compare them in terms of environmental impacts were modeled by using LCA. Works of Kim and Kim (2010), Palmieri et al. (2017), Salemdeeb et al. (2017), Salomone et al. (2013, 2017) have shown that improvement in environmental performance of studied processes when food waste is used as feed for animals and insects were seen as the best strategy. Comparative analysis of the LCA of different food waste management strategies (landfill, anaerobic digestion, incineration and composting) showed that the main differences between strategies in GHG emission are related to the assumptions made for the background systems, more than to the emissions generated in each studied process (Bernstad Saraiva Schott et al., 2016). Also, systematic analysis of LCA of different food waste management strategies has shown high variations in the absolute values of GHG emission depending on the applied 
strategy and study although landfill disposal emerges as the least favorable option in overall environmental impact (Bernstad and la Cour Jansen, 2012). Based on several studies, current modeling of environmental impacts is very inconclusive, with significant differences in the setup of boundary conditions of systems between studies making it very difficult to compare and extrapolate results as well as to make general conclusions (Bernstad and la Cour Jansen, 2012; Bernstad Saraiva Schott et al., 2016; Kim and Kim, 2010). Capability to minimize the food waste in all parts of the food chain, as requested by the EU Waste Framework Directive, could significantly affect energy efficiency, reduction of raw material use, reduction in water consumption and increasing reuse and recycling on site (EC, 2008). It is of note that consumers in western countries produce more food waste than the food industry and other stakeholders earlier in food supply chain so the food waste management strategies in households and analysis and inclusion of these approaches in overall environmental assessment of the food chain should be addressed in the future (Beretta et al., 2013; Gustafsson et al., 2013).

In the food waste sector, Saravia-Pinilla et al. (2016) showed an overview of separation and collection practices of household food waste in Sweden. They propose two systems for collection of food waste in households (a) use of food waste disposers in kitchen sinks and (b) collection of food waste in paper bags for further treatment. The comparison was made in relation to greenhouse gas emissions as well as primary energy utilization. Other similar studies were conducted in order to address the impacts of different household management strategies (Hebrok and Boks, 2017; Xu et al., 2016).

In the area of biomass use, La Villetta et al. (2017) discussed the possibility of opening the way to the use of biomass as alternative fuels. Among thermo-chemical treatments of biomass, gasification is particularly attractive for its release of syngas, suitable of being used in various combustion systems, including internal combustion engines. They demonstrated the operational feasibility and effectiveness of gasification technologies and proved long-term sustainability of this technology through the enhancement of fuel flexibility. Another model was used by Fitamo et al. (2016) modeling anaerobic bioconversion for simulating the anaerobic co-digestion of various types of urban organic waste, in order to develop strategies for controlling and optimizing the co-digestion process.

\subsection{System-based perspective}

The system-based perspective analyzes environmental management systems (EMS) and other types of environmental practices that exist on-site in the food chain. Latest ISO survey on ISO 14001 certification shows that more than 320,000 EMS certificates were issued in 200 countries, where the food chain participates with less than $4 \%$ (ISO, 2016b). An EMS is often a part of an integrated management system (Labodová, 2004) where in the food industry quality and food safety systems co-exist (Djekic et al., 2014b).

Djekic et al. (2014b) identified three time dimensions of EMS research in the food chain: ex ante (prior to implementation of an EMS), ongoing/mid-term (during implementation) and ex post (upon implementation). Ex ante dimension of research are drivers and motivation in implementing EMS; during EMS implementation, companies mainly report costs and financial issues while ex post dimension of research comprises of benefits and achieved effects of implemented EMS, regardless of the certification status. Environmental awareness is as an important trigger in implementing an EMS mainly due to its relation with environmental practices on-site (Djekic et al., 2016a). Gomez and Rodriguez (2011) recognize two types of companies depending on their level of awareness. The ones that develop competences to fulfill environmental legal requirements and the others that consider environmental performances in all decision-making processes. Nevertheless, the awareness about environmental issues is increasing and consumers are demanding healthier and more environmental friendly food products.

Various models were developed to assess the implementation of EMS. Basic models are questionnaires for evaluating levels of implementation and/or fulfilling environmental requirements. They vary from on-line questionnaires (off-site) to face-to-face interviews conducted by trained interviewers including on-site tours. In order to collect data, authors usually create structured questionnaires comprising of general demographic information of food companies as well as questions related to the reasons for implementing an EMS, effects, benefits and outputs, practices, etc. Assessment methods use various numeric tools to identify level of fulfilling of requirements (Djekic et al., 2016a), Likert scales from 'strongly disagree' to 'strongly agree' (Boiral and Henri, 2012; Chan and Wong, 2006; Jabbour, 2010) and ranking from 1 'the most important' to 10 'the least important' (Djekic et al., 2014b). Last but not least, there are also cases with open questions (Van Herzele et al., 2011). Modeling is essential in order to analyze the results provided by the questionnaires to obtain conclusions how to improve the food production systems from an environmental point of view.

Two directions of research can be found in this area. So called "top-down", where the perspective is the company and its environmental management. The other is a "bottom-up" approach by analyzing environmental practices on-site that provide added value regarding analysis of the current environmental practices in the food chain (Djekic et al., 2016a). Latest revision of ISO 14001 shifts environmental impacts towards sustainable resource management and climate change mitigation including life-cycle approach and effective communication with all stakeholders (ISO, 2015). It is expected that this will affect future trends towards improving environmental performance in the food industry (Djekic and Tomasevic, 2016).

\section{Environmental models in food industry - future perspectives}

Majority of environmental models were developed by environmental scientists and are generic regardless of the type of companies or products with limited environmental models for the food industry. Expanding the perspective and including specific food issues (Fig. 6) enables a powerful tool for defining a holistic perspective of environmental food industry models. This widening of the perspective is important in relation to the socio-economic dimensions of the food chain and food safety/food quality dimensions of food.

The food industry itself has its research challenges. Consumer as the last link in the food chain becomes more demanding in terms of diet requirements. Food preservation technologies introduce novel non-thermal technologies, while the food packaging industry offers innovations in delivering fresh food products of high quality with a longer shelf life. Global economies enable global food retailing where food transportation becomes a vital issue. Finally, the consequences of climate change on the food chain are studied, mainly from a food safety point of view. In this section, these food industry challenges are explored in terms of future perspectives of environmental models in food systems.

\subsection{Food diets and the environment}

From a systemic viewpoint, analyses from production to consumption have questioned the compatibility of environmental 
concerns and other aspects of food, such as nutrition or budget. Moreover, consumers are the last link in the value chain, therefore the adoption of sustainable diets by consumers will contribute to boost the sustainability of all the food chain. In fact, there is an increasing number of studies about the environmental consequences of diets. Among several diets tested by (Duchin, 2005), the Mediterranean-type vegetable-based diet was shown to satisfy both nutritional and environmental requirements, while reducing the pressure of agri-food systems on the environment. Moreover, Goulet et al. (2008) confirmed its compatibility with price concerns. Hallström et al. (2015) conclude from a review of 14 studies that changes in diet can lead up to $50 \%$ reduction of greenhouse gases and land use change. As a consequence of this research many countries are including sustainability or environmental criteria when defining their nutritional guidelines; for instance in the Netherlands (van Dooren and Aiking, 2016).

There is an increase of the overall consumption as a result of growth of world's population and increase of the consumption of meat per capita (Henchion et al., 2014). Nevertheless, many studies are appealing for a decrease of meat consumption, favoring the consumption of fruits and vegetables (Baroni et al., 2006; CarlssonKanyama, 1998; Pimentel and Pimentel, 2003). Such changes in diet would imply deep changes in the occupation of agricultural surfaces (Young and Kantor, 1999). In particular, a transfer of surfaces in favor of fruit, vegetable and legume production would be required. Eating meat is not only a nutritional need in respect to 'nutritional transition' of dietary patterns and consumption of foods with higher content in animal protein (Hawkesworth et al., 2010; Mathijs, 2015). It is determined by taste, odor, and texture, as well as by geographical area, culture, ethics, religion beliefs and wealth (Font-i-Furnols and Guerrero, 2014; Richardson et al., 1993).

The evaluation of diets is complex due to, on the one hand, the great variety of foods involved (because there no available LCA for all of them), and on the other hand to the system boundaries involved (some studies are from cradle-to-farm gate, others from cradle-to-retailer, etc). Pernollet et al. (2017) developed an approach that provides guidance for obtaining the best trade-off between available resources and the robustness of LCA results when assessing diets.

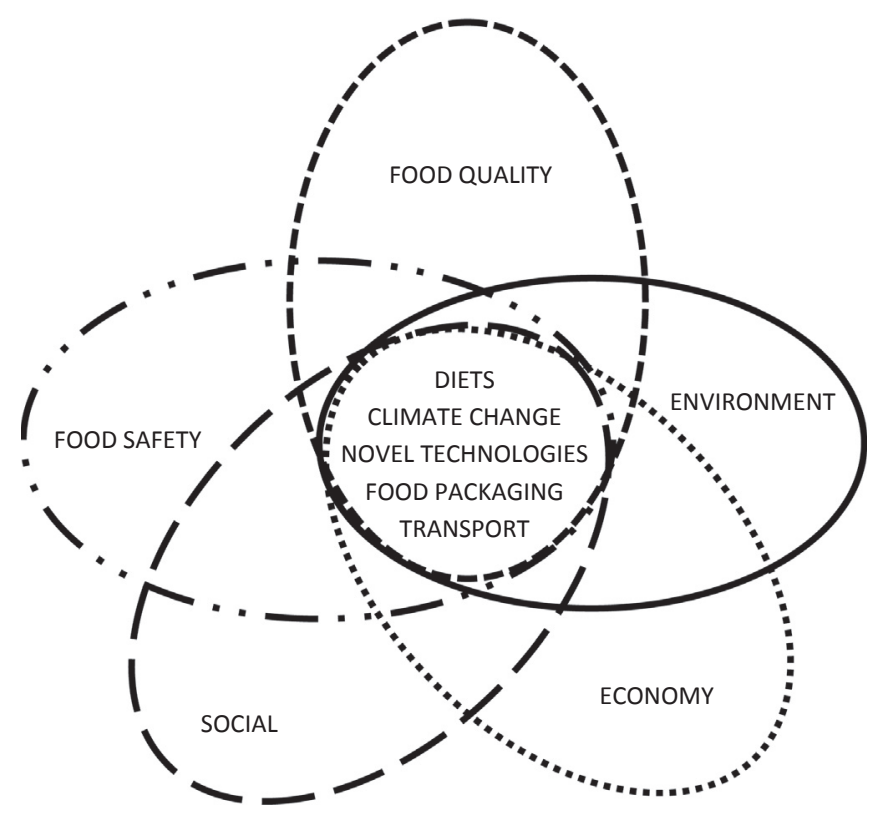

Fig. 6. Holistic approach for environmental models in food industry.
A customized LCA for protein rich food was performed by Head et al. (2014). These authors made database models and life cycle impact assessment results for protein rich foods, including the incorporation of recent developments in land transformation methodology. The authors developed an application, which was directly accessible to the consumer in the supermarket. The results have shown, that there were large differences between the product groups and also within the product groups.

Perignon et al. (2016) analyzed the compatibility of nutritional, financial and acceptability aspects of food products with the reduction of greenhouse gases emissions. They constitute a step in the multicriteria approach of food products (Bourguet et al., 2013; Thomopoulos et al., 2015), although based on aggregated statistical data rather than on specific well-described products. In Seconda et al. (2017), the environmental issue is approached in relation with organic food consumption. Ribal et al. (2016a) developed a model to design diets taking into account nutritional, climate change and economic aspects. To achieve this aim, these authors used an optimization technique, specifically integer goal programming.

Among the potential consequences of changes in diet, the direct and indirect land use change should be taken into account. Therefore, beyond the studies addressed to design and evaluate diets, there is a need to tackle the complexity of this issue both at regional and global scale and consequential LCA is a suitable and operational tool. In this sense, a recent study of de Oliveira Silva et al. (2016) explores the consequences of changes in beef consumption on GHG emissions by considering two alternative scenarios under a consequential LCA approach. In the decoupled livestock-deforestation (DLD) scenario, baseline deforestation rates controlled by effective policy are assumed; the second scenario, coupled livestock-deforestation (CLD), implies that shifts in beef demand alter deforestation rates. Results show that in DLD scenario, increased production leads to more efficient systems with boosted stocks, reducing GHG emissions. The analysis contributes to the sustainable intensification debate, highlighting the role of effective deforestation policies.

\subsection{Novel food technologies}

Food processors are increasing their interest in novel technologies not only to provide food products with improved quality, but also to reduce the environmental footprint of the products and the processing cost (Pereira and Vicente, 2010). Novel technologies, such as pulsed electric field treatment or high-pressure treatment, have been developed for the food industry (Jermann et al., 2015), in order to replace energy consuming techniques like sterilization or pasteurization, and to achieve microbial inactivation under mild conditions and in shorter time (Toepfl et al., 2006) or to inactivate certain enzymes and prevent undesired changes in food. Other promising novel technologies are high power ultrasound, low temperature drying and the use of supercritical $\mathrm{CO}_{2}$ for extraction or microbial inactivation (Ortuño et al., 2014; Santacatalina et al., 2016).

Analysis and comparison of environmental impacts of novel processing techniques as well as novel products can pose a challenge mainly because of the differences in the scale of the facilities and food processed (meat, egg, fruit, vegetables, liquid food ...). In most of the cases, these techniques are not implemented in large scale industrial facilities and are often studied on lab scale or pilot level without deep analysis of the complete process (Hospido et al., 2010).

LCA has a great potential for driving the development of products and processes. Through LCA, novel processing technologies can be compared with existing commercial alternatives and environmental hotspots can be also identified (Hetherington et al., 2014). 
According to Hospido et al. (2010), when novel technologies are evaluated from an environmental point of view the main difficulties are: (i) the lack of real data for the inventory phase, which is often based on lab scale information or theoretical data; (ii) the definition of the FU for comparative studies since new products or processes might have unique properties and (iii) manufacture of products or processes can be expected to start several years ahead and assumptions on surrounding systems will be required. These authors proposed an approach for the environmental analysis of novel food technologies. The working procedure defined is a starting point for the evaluation of novel food technologies through LCA.

Comparative LCA studies of conventional and novel technologies can be found in the literature. Pardo and Zufía (2012) evaluated the environmental impacts of some traditional and novel food preservation technologies with the aim to contribute to the development of more sustainable food products. Some general improvements were identified and environmental criteria were provided in order to select the more adequate preservation method when designing new food products. Valsasina et al. (2017) compared ultra-high pressure homogenization with common thermal treatment for milk. The upscaling showed a decrease in carbon footprint up to $88 \%$ achievable with improvements in efficiency.

High energy consumption process of superheated steam drying (SSD) was studied by Li et al. (2016). This study presents a comprehensive overview of state-of-the-art of design aspects, energetic performances, and mathematical modeling. SSD is presented as an efficient drying method because of its high energy efficiency, safety, high drying rate, and high quality of final product. The research results show that the energy consumption in SSD is lower compared with conventional hot air drying method. However, the available data on comprehensive analysis and modeling of environmental impacts of this technique in comparison to traditional ones are still limited.

Aganovic et al. (2017) studied the energy balance and LCA of pulsed electric fields and high pressure processing technologies in comparison to conventional thermal processing applied to the preservation of tomato and watermelon juices. At pilot scale, both pulsed electric field and high pressure processing technologies presented higher energy consumption expressed per liter of juice, indicating the necessity for further development of models for assessing the overall performance of the process and its environmental impacts.

In the future, more studies related to comparison of environmental impacts of novel and conventional techniques will be needed aiming at improving the environmental performance of food industry. Nevertheless, comparisons must cover not only the environmental aspects of the process, but also other factors as the quality of the final product or investment costs.

\subsection{Environmental perspective of food packaging}

The food packaging technologies are being improved in response to the demands toward fresh, mildly preserved, convenient, delicious, safe, wholesome and quality food products with a longer shelf life (Realini and Marcos, 2014). Innovations in packaging are a tool for increasing the global sustainability of food production and reducing food loss and waste achieved through shelf life (Gutierrez et al., 2017). Licciardello (2017) emphasizes that various LCA studies show different environmental impacts of food packaging. In some occasions, food packaging holds $1-10 \%$ of overall environmental burden (Silvenius et al., 2014) while in other it is pointed as the most significant impact polluter in the food chain (Manfredi and Vignali, 2015). When determining which package is more environmentally friendly, the whole life cycle of the package system must be considered. There are four main dimensions of research that must be taken into account: (i) type of food packaging material; (ii) disposal methods related to food packaging; (iii) potentials in extending shelf life and reducing food waste and (iv) balancing priorities (Marsh and Bugusu, 2007).

Sustainability of food packaging can be achieved at three levels: (i) at the materials level, by using environmental friendly packaging materials; (ii) at the production level, through more energyefficient processes for production of food packaging materials; and (iii) at the waste management level, considering reuse, recycling and biodegradation (Peelman et al., 2013). Food packaging in most occasions consists of primary packaging (in direct contact with food) and secondary packaging that contains a number of primary packaging units (Wikström et al., 2014). Food packaging innovations, such as development of functional packaging, should have the potential to increase food shelf life and reduce the possibility of food to turn into a waste (Licciardello, 2017).

The most explored strategy for decreasing the environmental impact of food packaging is by minimizing the packaging material impact through light-weighting of packaging materials and/or removal of excessive packaging (van Sluisveld and Worrell, 2013). Another approach is the selection of more renewable materials, and enhancing the efficiency and energy consumption associated with sourcing, producing and converting packaging materials (Wikström et al., 2014). However, putting prevention as a waste hierarchy principle into practice can be observed in the promotion of zero-packaging grocery stores (Beitzen-Heineke et al., 2017).

In the last years, an issue related to packaging that has been tackled is consumer behavior and its relation with food waste and the end of life stage. Williams and Wikström (2011) deploy environmental impacts of food packaging and explore recycling possibilities to modeling food waste reduction. An additional perspective is in improving packaging attributes that influence behavior such as "easy to empty", easy to clean", "easy to separate into different fractions", "easy to fold" and "information on how to sort" (Wikström et al., 2016). Integration of behavioral sciences into LCA to improve packaging and provide valuable insights to ecodesign is a future challenge (Gutierrez et al., 2017; Williams and Wikström, 2011).

\subsection{Food transportation}

Although present in all industries, transportation of food has been identified as a specific "food process" and an increased attention to the environmental impact of transportation in food systems became a tool in environmental and food policies, mainly focused on the reduction of global warming potential (Coley et al., 2009). According to Pretty et al. (2005) national road transport for food distribution and shopping is an important part of food-related environmental costs in Great Britain. Some authors assume that transportation of trade goods enhances over $20 \%$ of total global $\mathrm{CO}_{2}$ emissions (Davis and Caldeira, 2010; López et al., 2015). Global warming potential is the major environmental impact connected to transport food mile (Coley et al., 2009). Nevertheless, a growing number of LCA studies showed that local or domestic production does not necessarily have advantages over imports from an environmental point of view and that transport mode is more important than transport distance (Nemecek et al., 2016).

Some trade-offs have been found when studying the impact of transport. Schlich and Fleissner (2005) insist on the importance of the organization and size of the production-processingdistribution chain on the energetic efficiency. On a per unit basis, supply chains relying on extensive use of small capacity vehicles are likely to be less energy efficient than their larger-scale counterparts 
(Wakeland et al., 2012). Another aspect to be taken into account is food seasonality. According to Sim et al. (2007) if fresh products are to be offered all year round, two sourcing strategies are essentially available: import produce from overseas, or create an artificial environment (usually through heating and lighting greenhouses) and produce locally. Some studies show that the energy used for greenhouse production mitigates the energy used in transportation thus justifying a strategy of overseas sourcing (Hospido et al., 2009; i Canals et al., 2008). A classic challenge for supply chain managers is to strike the right balance between transportation and storage costs (Wakeland et al., 2012).

Supply chains are complex, and food supply chains are especially challenging because of seasonality, freshness, spoilage, and sanitary considerations. In spite of different approaches to this issue many authors conclude that transportation of food becomes a challenge, especially due to the fact that import of food is growing (Schnell, 2013; Webb et al., 2013).

\subsection{Climate change and food safety}

Fig. 6 points out the importance of the relationship between food safety, quality and environmental aspects in food systems. Manzini et al. (2014) through a case study about edible oils, demonstrated the importance of conducting safety and quality assessments combined with environmental analyses for the development of sustainable food supply chains. Climate change and climate variability are among the multiple factors that can provoke changes in the nature and occurrence of food safety hazards. (Tirado et al., 2010). Holvoet et al. (2014) and Miraglia et al. (2009) confirmed that climatic conditions have an impact on food safety, incidence and prevalence of foodborne diseases. Temperature and precipitation patterns are related with contamination pathway, growth and survival of bacteria (Liu et al., 2015). Several papers explored the effects of climatic conditions on the production of fresh fruit and vegetables (Holvoet et al., 2014; Kirezieva et al., 2015; Liu et al., 2013; Uyttendaele et al., 2015). Climate change on agriculture includes variations in the seasons, modifications of the areas suitable for growing crops, grazing of livestock, production efficiency of livestock and changes in plant pests (Miraglia et al., 2009). Various assessment models provide evidence that climate change will affect agricultural yields and earnings, food prices, reliability of delivery, food quality and food safety. As a result, lowincome producers and consumers of food will be more vulnerable to climate change owing to their comparatively limited ability to invest in adaptive technologies under increasing climatic risks (Vermeulen et al., 2012). Extreme weather events such as floods and droughts may lead to contamination of soil, agricultural lands, water and food and animal feed with pathogens, chemicals and other hazardous substances, originating from sewage, agriculture and industrial settings (Tirado et al., 2010). Djekic et al. (2016b) confirmed a relationships between hygiene indicators in takeaways and climatic conditions, mostly temperature and precipitation concluding that changes in average temperature directly affect hygiene indicators in open work environments. As an answer to the threat of climate change on food safety, Liu et al. (2015) developed a climate change tool for food safety scenario analysis with the potential of using this tool with other impact models, such as bacterial and mycotoxin growth and pesticide models. Uyttendaele et al. (2015) in their review on the impacts of climate change on food safety concluded that climate change has an impact not only on crop production or food security but also on food safety, incidence and prevalence of foodborne diseases. For that reason the inclusion of all these aspects when modeling environmental food processes is important.

\section{Conclusion}

Due to the worldwide diversity of food systems and their interactions with the environment, environmental aspects of food are very complex to tackle. Models developed to explain environmental issues of food systems are representatives of different approaches. On one hand, generic environmental models developed by environmental scientists are used in the food industry. On the other hand, models have been developed by food scientists in order to analyze environmental interactions on a smaller scale.

In general, main stream environmental research in food industry can be categorized as product, process or system oriented. Product based perspective focuses on a specific food and its environmental impact throughout the food chain/life cycle. On the other side, perspectives of research can go from the company level, analyzing environmental impacts of main stakeholders in the food chain, to specific process activities like water treatment or energy consumption. However, when widening the panorama additional dimensions are revealed. Food diets highlight the consumer's role in influencing the environmental impact. Novel food technologies and food packaging uncover an environmental outlook to food quality and food safety aspects related to preservation of nutrients and sensory characteristics and prolonging shelf-life. Environmental issues of food transport point up the necessity of selecting the transport mode and optimizing transportation routes to deliver food to consumers world-wide. Finally, as a result of climate change, feedback from this environmental concern also influences food production from a food safety perspective.

A future extension of this study will consist of comparing, integrating and validating the results of these researches. However, given the great diversity of food technologies and the complexity of food chains, eating habits and cultural specificities, the promotion of environment-friendly models and solutions is the utmost challenge.

\section{Acknowledgement}

The authors would like to acknowledge networking support by the COST Action CA15118 (FoodMC).

\section{References}

Aganovic, K., Smetana, S., Grauwet, T., Toepfl, S., Mathys, A., Van Loey, A., Heinz, V., 2017. Pilot scale thermal and alternative pasteurization of tomato and watermelon juice: an energy comparison and life cycle assessment. J. Clean. Prod.141, $514-525$

Akkerman, R., Farahani, P., Grunow, M., 2010. Quality, safety and sustainability in food distribution: a review of quantitative operations management approaches and challenges. Or Spectr. 32, 863-904.

Al-Ansari, T., Korre, A., Nie, Z., Shah, N., 2014. Development of a Life Cycle Assessment Model for the Analysis of the Energy, Water and Food Nexus.

Arzoumanidis, I., Raggi, A., Petti, L., 2014. Considerations when applying simplified LCA approaches in the wine sector. Sustainability 6, 5018-5028.

Arzoumanidis, I., Salomone, R., Petti, L., Mondello, G., Raggi, A., 2017. Is there a simplified LCA tool suitable for the agri-food industry? An assessment of selected tools. J. Clean. Prod. 149, 406-425.

Avadí, A., Bolaños, C., Sandoval, I., Ycaza, C., 2015. Life cycle assessment of Ecuadorian processed tuna. Int. J. Life Cycle Assess. 20, 1415-1428.

Avadí, A., Nitschelm, L., Corson, M., Vertès, F., 2016. Data strategy for environmental assessment of agricultural regions via LCA: case study of a French catchment. Int. J. Life Cycle Assess. 21, 476-491.

Baiano, A., 2014. Recovery of biomolecules from food wastes-a review. Molecules 19, 14821-14842.

Banga, J.R., Balsa-Canto, E., Moles, C.G., Alonso, A.A., 2003. Improving food processing using modern optimization methods. Trends Food Sci. Technol. 14, $131-144$.

Baroni, L., Cenci, L., Tettamanti, M., Berati, M., 2006. Evaluating the environmental impact of various dietary patterns combined with different food production systems. Eur. J. Clin. Nutr. 61, 279-286.

Bartl, K., Verones, F., Hellweg, S., 2012. Life cycle assessment based evaluation of regional impacts from agricultural production at the Peruvian coast. Environ. Sci. Technol. 46, 9872-9880. 
Battini, D., Persona, A., Sgarbossa, F., 2014. A sustainable EOQ model: theoretical formulation and applications. Int. J. Prod. Econ. 149, 145-153.

Beitzen-Heineke, E.F., Balta-Ozkan, N., Reefke, H., 2017. The prospects of zeropackaging grocery stores to improve the social and environmental impacts of the food supply chain. J. Clean. Prod. 140, 1528-1541.

Beretta, C., Stoessel, F., Baier, U., Hellweg, S., 2013. Quantifying food losses and the potential for reduction in Switzerland. Waste Manag. 33, 764-773.

Bernstad, A., la Cour Jansen, J., 2012. Review of comparative LCAs of food waste management systems-current status and potential improvements. Waste Manag. 32, 2439-2455 (New York, N.Y.).

Bernstad Saraiva Schott, A., Wenzel, H., la Cour Jansen, J., 2016. Identification of decisive factors for greenhouse gas emissions in comparative life cycle assessments of food waste management - An analytical review. J. Clean. Prod. 119, $13-24$.

Bessou, C., Basset-Mens, C., Latunussa, C., Vélu, A., Heitz, H., Vannière, H., Caliman, J.-P., 2016. Partial modelling of the perennial crop cycle misleads LCA results in two contrasted case studies. Int. J. Life Cycle Assess. 21, 297-310.

Bessou, C., Basset-Mens, C., Tran, T., Benoist, A., 2013. LCA applied to perennial cropping systems: a review focused on the farm stage. Int. J. Life Cycle Assess. $18,340-361$.

Boiral, O., Henri, J.-F., 2012. Modelling the impact of ISO 14001 on environmental performance: a comparative approach. J. Environ. Manag. 99, 84-97.

Bourguet, J.-R., Thomopoulos, R., Mugnier, M.-L., Abécassis, J., 2013. An artificia intelligence-based approach to deal with argumentation applied to food quality in a public health policy. Expert Syst. Appl. 40, 4539-4546.

BSI, 2008. PAS 220:2008 Prerequisite Programmes on Food Safety for Food Manufacturing.

CAC, 2003. CAC/RCP 1-1969, Rev.4-2003 Recommended International Code of Practice - General Principles of Food Hygiene Codex Alimentarius Commission.

Campdepadrós, M., Stchigel, A.M., Romeu, M., Quilez, J. Solà, R., 2012. Effectivenes of two sanitation procedures for decreasing the microbial contamination levels (including Listeria monocytogenes) on food contact and non-food contact surfaces in a dessert-processing factory. Food Control. 23, 26-31.

Carlsson-Kanyama, A., 1998. Climate change and dietary choices - how can emissions of greenhouse gases from food consumption be reduced? Food Policy 23, 277-293.

Cerutti, A.K., Beccaro, G.L., Bruun, S., Bosco, S., Donno, D., Notarnicola, B., Bounous, G., 2014. Life cycle assessment application in the fruit sector: state of the art and recommendations for environmental declarations of fruit products. J. Clean. Prod. 73, 125-135.

Chan, E.S.W., Wong, S.C.K., 2006. Motivations for ISO 14001 in the hotel industry. Tour. Manag. 27, 481-492.

Chen, H., Jiang, W., Yang, Y., Yang, Y., Man, X., 2017. State of the art on food waste research: a bibliometrics study from 1997 to 2014. J. Clean. Prod. 140, 840-846.

Coley, D., Howard, M., Winter, M., 2009. Local food, food miles and carbon emis sions: a comparison of farm shop and mass distribution approaches. Food Policy 34, 150-155.

Corrado, S., Ardente, F., Sala, S., Saouter, E., 2017. Modelling of food loss within life cycle assessment: from current practice towards a systematisation. J. Clean. Prod. 140, 847-859.

Coulomb, D., 2008. Refrigeration and cold chain serving the global food industry and creating a better future: two key IIR challenges for improved health and environment. Trends Food Sci. Technol. 19, 413-417.

Dahiya, S., Sarkar, O., Swamy, Y.V., Venkata Mohan, S., 2015. Acidogenic fermentation of food waste for volatile fatty acid production with co-generation of biohydrogen. Bioresour. Technol. 182, 103-113.

Dandres, T., Gaudreault, C., Tirado-Seco, P., Samson, R., 2011. Assessing nonmarginal variations with consequential LCA: application to European energy sector. Renew. Sustain. energy Rev. 15, 3121-3132.

Davis, S.J., Caldeira, K., 2010. Consumption-based accounting of CO2 emissions. Proc Natl. Acad. Sci. 107, 5687-5692.

de Oliveira Silva, R., Barioni, L.G., Hall, J.A.J., Folegatti Matsuura, M., Zanett Albertini, T., Fernandes, F.A., Moran, D., 2016. Increasing beef production could lower greenhouse gas emissions in Brazil if decoupled from deforestation. Nat. Clim. Chang. 6, 493-497.

de Vries, M., de Boer, I.J.M., 2010. Comparing environmental impacts for livestock products: a review of life cycle assessments. Livest. Sci. 128, 1-11.

De Vries, M., Van Middelaar, C., De Boer, I., 2015. Comparing environmental impacts of beef production systems: a review of life cycle assessments. Livest. Sci. 178, $279-288$.

Deepanraj, B., Sivasubramanian, V., Jayaraj, S., 2017. Multi-response optimization of process parameters in biogas production from food waste using Taguchi-Grey relational analysis. Energy Convers. Manag. 141, 429-438.

Del Borghi, A., Gallo, M., Strazza, C., Del Borghi, M., 2014. An evaluation of environmental sustainability in the food industry through Life Cycle Assessment: the case study of tomato products supply chain. J. Clean. Prod. 78, 121-130.

Djekic, I., 2015. Environmental impact of meat industry - current status and future perspectives. Procedia Food Sci. 5, 61-64.

Djekic, I., Blagojevic, B., Antic, D., Cegar, S., Tomasevic, I., Smigic, N., 2016a. Assessment of environmental practices in Serbian meat companies. J. Clean. Prod. 112 (Part 4), 2495-2504.

Djekic, I., Kuzmanovic, J., Andelkovic, A., Saracevic, M., Stojanovic, M.M., Tomasevic, I., 2016b. Relationships among hygiene indicators in take-away foodservice establishments and the impact of climatic conditions. J. Appl. Microbiol. 121, 863-872.
Djekic, I., Miocinovic, J., Tomasevic, I., Smigic, N., Tomic, N., 2014a. Environmental life-cycle assessment of various dairy products. J. Clean. Prod. 68, 64-72.

Djekic, I., Radović, Č., Lukić, M., Stanišić, N., Lilić, S., 2015. Environmental life-cycle assessment in production of pork products. Meso XVII 345-351.

Djekic, I., Rajkovic, A., Tomic, N., Smigic, N., Radovanovic, R., 2014b. Environmental management effects in certified Serbian food companies. J. Clean. Prod. 76, 196-199.

Djekic, I., Tomasevic, I., 2016. Environmental impacts of the meat chain - Current status and future perspectives. Trends Food Sci. Technol. 54, 94-102.

Djukić-Vuković, A.P., Mojović, L.V., Semenčenko, V.V., Radosavljević, M.M., Pejin, J.D., Kocić-Tanackov, S.D., 2015. Effective valorisation of distillery stillage by integrated production of lactic acid and high quality feed. Food Res. Int. 73, 75-80.

Duchin, F., 2005. Sustainable consumption of food: a framework for analyzing scenarios about changes in diets. J. Ind. Ecol. 9, 99-114.

Dutilh, C.E., Kramer, K.J., 2000. Energy consumption in the food chain: comparing alternative options in food production and consumption. Ambio J. Hum. Environ. 29, 98-101.

EC, 2008. In: Union, O.J.o.E. (Ed.), Directive 2008/98/EC of the European Parliament and of the council of 19 November 2008 on waste and repealing certain Directives. European Commission, Brussels, Belgium, pp. 3-30. L 312.

Escobar, N., Manrique-de-Lara-Peñate, C., Sanjuán, N., Clemente, G., Rozakis, S., 2017. An agro-industrial model for the optimization of biodiesel production in Spain to meet the European GHG reduction targets. Energy 120, 619-631.

Fitamo, T., Boldrin, A., Dorini, G., Boe, K., Angelidaki, I., Scheutz, C., 2016. Optimising the anaerobic co-digestion of urban organic waste using dynamic bioconversion mathematical modelling. Water Res. 106, 283-294.

Font-i-Furnols, M., Guerrero, L., 2014. Consumer preference, behavior and perception about meat and meat products: an overview. Meat Sci. 98, 361-371.

Garcia, D.J., You, F., 2016. The water-energy-food nexus and process systems engineering: a new focus. Comput. Chem. Eng. 91, 49-67.

Gomez, A., Rodriguez, M.A., 2011. The effect of ISO 14001 certification on toxic emissions: an analysis of industrial facilities in the north of Spain. J. Clean. Prod. 19, 1091-1095.

Goulet, J., Lamarche, B., Lemieux, S., 2008. A nutritional intervention promoting a Mediterranean food pattern does not affect total daily dietary cost in North American women in free-living conditions. J. Nutr. 138, 54-59.

Grunert, K.G., Hieke, S., Wills, J., 2014. Sustainability labels on food products: consumer motivation, understanding and use. Food Policy 44, 177-189.

Gussow, J.D., Clancy, K.L., 1986. Dietary guidelines for sustainability. J. Nutr. Educ. 18, $1-5$.

Gustafsson, J., Cederberg, C., Sonesson, U., Emanuelsson, A., 2013. The Methodology of the FAO Study: global Food Losses and Food Waste-Extent, Causes and Prevention"-FAO, 2011. SIK Institutet för livsmedel och bioteknik.

Gutierrez, M.M., Meleddu, M., Piga, A., 2017. Food losses, shelf life extension and environmental impact of a packaged cheesecake: a life cycle assessment. Food Res. Int. 91, 124-132.

Hallström, E., Carlsson-Kanyama, A., Börjesson, P., 2015. Environmental impact of dietary change: a systematic review. J. Clean. Prod. 91, 1-11.

Hawkesworth, S., Dangour, A.D., Johnston, D., Lock, K., Poole, N., Rushton, J., Uauy, R., Waage, J., 2010. Feeding the world healthily: the challenge of measuring the effects of agriculture on health. Philos. Trans. R. Soc. Lond. B Biol. Sci. 365, 3083-3097.

Head, M., Sevenster, M., Odegard, I., Krutwagen, B., Croezen, H., Bergsma, G., 2014. Life cycle impacts of protein-rich foods: creating robust yet extensive life cycle models for use in a consumer app. J. Clean. Prod. 73, 165-174.

Hebrok, M., Boks, C., 2017. Household food waste: drivers and potential intervention points for design-An extensive review. J. Clean. Prod. 151, 380-392.

Heller, M.C., Keoleian, G.A., Willett, W.C., 2013. Toward a life cycle-based, diet-level framework for food environmental impact and nutritional quality assessment: a critical review. Environ. Sci. Technol. 47, 12632-12647.

Henchion, M., McCarthy, M., Resconi, V.C., Troy, D., 2014. Meat consumption: trends and quality matters. Meat Sci. 98, 561-568.

Henriksson, P.J., Guinée, J.B., Kleijn, R., de Snoo, G.R., 2012. Life cycle assessment of aquaculture systems-a review of methodologies. Int. J. life cycle Assess. 17, 304-313.

Hernández-Carranza, P., Ávila-Sosa, R., Guerrero-Beltrán, J., Navarro-Cruz, A., Corona-Jiménez, E., Ochoa-Velasco, C., 2016. Optimization of antioxidant compounds extraction from fruit by-products: apple Pomace, orange and Banana Peel. J. Food Process. Preserv. 40 (1), 103-115.

Hetherington, A.C., Borrion, A.L., Griffiths, O.G., McManus, M.C., 2014. Use of LCA as a development tool within early research: challenges and issues across different sectors. Int. J. Life Cycle Assess. 19, 130-143.

Hochschorner, E., Finnveden, G., 2003. Evaluation of two simplified life cycle assessment methods. Int. J. Life Cycle Assess. 8, 119.

Holvoet, K., Sampers, I., Seynnaeve, M., Uyttendaele, M., 2014. Relationships among hygiene indicators and enteric pathogens in irrigation water, soil and lettuce and the impact of climatic conditions on contamination in the lettuce primary production. Int. J. Food Microbiol. 171, 21-31.

Hospido, A., Davis, J., Berlin, J., Sonesson, U., 2010. A review of methodological issues affecting LCA of novel food products. Int. J. life cycle Assess. 15, 44-52.

Hospido, A., I Canals, L.M., McLaren, S., Truninger, M., Edwards-Jones, G., clift, R., 2009. The role of seasonality in lettuce consumption: a case study of environmental and social aspects. Int. J. Life Cycle Assess. 14, 381-391.

i Canals, L.M., Muñoz, I., Hospido, A., Plassmann, K., McLaren, S., Edwards-Jones, G., 
Hounsome, B., 2008. Life Cycle Assessment (LCA) of Domestic vs. Imported Vegetables. Case studies on Broccoli, Salad crops and green Beans. Centre for Environmental Strategy, University of Surrey, Guildford, UK.

ISO, 2005. ISO vol. 22000:2005 Food Safety Management Systems - Requirements for Any Organization in the Food Chain. International Organization for Standardization, Geneva, Switzerland.

ISO, 2006. ISO vol. 14040:2006 Environmental Management - Life Cycle Assessment - Principles and Framework. International organization for Standardization, Geneva, Switzerland.

ISO, 2015. ISO vol. 14001:2004 Environmental Management Systems - Requirements with Guidance for Use. International Organization for Standardization, Geneva, Switzerland.

ISO, 2016a. ISO vol. 14021:2016 Environmental Labels and Declarations - SelfDeclared Environmental Claims (Type II environmental labelling). International Organization for Standardization, Geneva, Switzerland.

ISO, 2016b. The ISO Survey of Certifications 2015. International Organization for Standardization, Geneva, Switzerland.

Jabbour, C.J.C., 2010. Non-linear pathways of corporate environmental management: a survey of ISO 14001-certified companies in Brazil. J. Clean. Prod. 18, $1222-1225$.

Jacquemin, L., Pontalier, P.-Y., Sablayrolles, C., 2012. Life cycle assessment (LCA) applied to the process industry: a review. Int. J. Life Cycle Assess. 17, 1028-1041.

Jermann, C., Koutchma, T., Margas, E., Leadley, C., Ros-Polski, V., 2015. Mapping trends in novel and emerging food processing technologies around the world. Innovative Food Sci. Emerg. Technol. 31, 14-27.

Kim, M.-H., Kim, J.-W., 2010. Comparison through a LCA evaluation analysis of food waste disposal options from the perspective of global warming and resource recovery. Sci. Total Environ. 408, 3998-4006.

Kirezieva, K., Jacxsens, L., van Boekel, M.A.J.S., Luning, P.A., 2015. Towards strategies to adapt to pressures on safety of fresh produce due to climate change. Food Res. Int. 68, 94-107.

La Villetta, M., Costa, M., Massarotti, N., 2017. Modelling approaches to biomass gasification: a review with emphasis on the stoichiometric method. Renew. Sustain. Energy Rev. 74, 71-88.

Labodová, A., 2004. Implementing integrated management systems using a risk analysis based approach. J. Clean. Prod. 12, 571-580.

Leitzmann, C., 2002. Nutrition Ecology: Origin and Definition, Forum of Nutrition, pp. 220-221.

Li, J., Liang, Q.-C., Bennamoun, L., 2016. Superheated steam drying: design aspects, energetic performances, and mathematical modeling. Renew. Sustain. Energy Rev. 60, 1562-1583.

Licciardello, F., 2017. Packaging, blessing in disguise. Review on its diverse contribution to food sustainability. Trends Food Sci. Technol. 65, 32-39.

Liu, C., Hofstra, N., Franz, E., 2013. Impacts of climate change on the microbial safety of pre-harvest leafy green vegetables as indicated by Escherichia coli 0157 and Salmonella spp. Int. J. Food Microbiol. 163, 119-128.

Liu, C., Hofstra, N., Leemans, R., 2015. Preparing suitable climate scenario data to assess impacts on local food safety. Food Res. Int. 68, 31-40.

López, L.-A., Cadarso, M.-A., Gómez, N., Tobarra, M.-Á, 2015. Food miles, carbon footprint and global value chains for Spanish agriculture: assessing the impact of a carbon border tax. J. Clean. Prod. 103, 423-436.

Manfredi, M., Vignali, G., 2015. Comparative life cycle assessment of hot filling and aseptic packaging systems used for beverages. J. Food Eng. 147, 39-48.

Manzini, R., Accorsi, R., 2013. The new conceptual framework for food supply chain assessment. J. Food Eng. 115, 251-263.

Manzini, R., Accorsi, R., Ayyad, Z., Bendini, A., Bortolini, M., Gamberi, M., Valli, E., Gallina Toschi, T., 2014. Sustainability and quality in the food supply chain. A case study of shipment of edible oils. Br. Food J. 116, 2069-2090.

Marsh, K., Bugusu, B., 2007. Food packaging-Roles, materials, and environmental issues. J. Food Sci. 72, R39-R55.

Masoni, P., Sara, B., Scimia, E., Raggi, A., 2004. VerdEE: a tool for adoption of life cycle assessment in small and medium sized enterprises in Italy. Prog. Ind. Ecol. Int. J. 1, 203-228.

Mathijs, E., 2015. Exploring future patterns of meat consumption. Meat Sci. 109, $112-116$.

McAuliffe, G.A., Chapman, D.V., Sage, C.L., 2016. A thematic review of life cycle assessment (LCA) applied to pig production. Environ. Impact Assess. Rev. 56, $12-22$.

Milà i Canals, L., Burnip, G.M., Cowell, S.J., 2006. Evaluation of the environmental impacts of apple production using Life Cycle Assessment (LCA): case study in New Zealand. Agric. Ecosyst. Environ. 114, 226-238.

Miraglia, M., Marvin, H.J.P., Kleter, G.A., Battilani, P., Brera, C., Coni, E., Cubadda, F., Croci, L., De Santis, B., Dekkers, S., Filippi, L., Hutjes, R.W.A., Noordam, M.Y. Pisante, M., Piva, G., Prandini, A., Toti, L., van den Born, G.J., Vespermann, A., 2009. Climate change and food safety: an emerging issue with special focus on Europe. Food Chem. Toxicol. 47, 1009-1021.

Moore-Lappé, F., 1971. Diet for a Small Planet. Ballantine, New York.

Mourad, M., 2016. Recycling, recovering and preventing "food waste": competing solutions for food systems sustainability in the United States and France. J. Clean. Prod. 126, 461-477.

Mouron, P., Nemecek, T., Scholz, R.W., Weber, O., 2006a. Management influence on environmental impacts in an apple production system on Swiss fruit farms: combining life cycle assessment with statistical risk assessment. Agric. Ecosyst. Environ. 114, 311-322.

Mouron, P., Scholz, R.W., Nemecek, T., Weber, O., 2006b. Life cycle management on
Swiss fruit farms: Relating environmental and income indicators for applegrowing. Ecol. Econ. 58, 561-578.

Nemecek, T., Jungbluth, N., I Canals, L.M., Schenck, R., 2016. Environmental impacts of food consumption and nutrition: where are we and what is next? Int. J. Life Cycle Assess. 21, 607-620.

Notarnicola, B., Tassielli, G., Renzulli, P.A., 2012. Modeling the agri-food industry with life cycle assessment. Life cycle Assess. Handb. A guide Environ. Sustain. Prod. 159-183.

Nucci, B., Puccini, M., Pelagagge, L., Vitolo, S., Nicolella, C., 2014. Improving the environmental performance of vegetable oil processing through LCA. J. Clean. Prod. 64, 310-322.

Ortuño, C., Balaban, M., Benedito, J., 2014. Modelling of the inactivation kinetics of Escherichia coli, Saccharomyces cerevisiae and pectin methylesterase in orange juice treated with ultrasonic-assisted supercritical carbon dioxide. J. Supercrit. Fluids 90, 18-26.

Pagan, B., Prasad, P., 2007. The Queensland food eco-efficiency project: reducing risk and improving competitiveness. J. Clean. Prod. 15, 764-771.

Palmieri, N., Forleo, M.B., Salimei, E., 2017. Environmental impacts of a dairy cheese chain including whey feeding: an Italian case study. J. Clean. Prod. 140, 881-889.

Pardo, G., Zufía, J., 2012. Life cycle assessment of food-preservation technologies J. Clean. Prod. 28, 198-207.

Peelman, N., Ragaert, P., De Meulenaer, B., Adons, D., Peeters, R., Cardon, L., Van Impe, F., Devlieghere, F., 2013. Application of bioplastics for food packaging. Trends Food Sci. Technol. 32, 128-141.

Pelletier, N.L., Ayer, N.W., Tyedmers, P.H., Kruse, S.A., Flysjo, A., Robillard, G., Ziegler, F., Scholz, A.J., Sonesson, U., 2007. Impact categories for life cycle assessment research of seafood production systems: review and prospectus. Int. J. Life Cycle Assess. 12, 414-421.

Pereira, R., Vicente, A., 2010. Environmental impact of novel thermal and nonthermal technologies in food processing. Food Res. Int. 43, 1936-1943.

Perignon, M., Masset, G., Ferrari, G., Barré, T., Vieux, F., Maillot, M., Amiot, M.-J. Darmon, N., 2016. How low can dietary greenhouse gas emissions be reduced without impairing nutritional adequacy, affordability and acceptability of the diet? A modelling study to guide sustainable food choices. Public Health Nutr. $1-13$.

Pernollet, F., Coelho, C.R.V., van der Werf, H.M.G., 2017. Methods to simplify diet and food life cycle inventories: accuracy versus data-collection resources. J. Clean Prod. 140 (Part 2), 410-420.

Perrin, A., Basset-Mens, C., Gabrielle, B., 2014. Life cycle assessment of vegetable products: a review focusing on cropping systems diversity and the estimation of field emissions. Int. J. Life Cycle Assess. 19, 1247-1263.

Pimentel, D., Pimentel, M., 2003. Sustainability of meat-based and plant-based diets and the environment. Am. J. Clin. Nutr. 78, 660S-663S.

Ponsioen, T., Van Der Werf, H., 2017. Five propositions to harmonize environmental footprints of food and beverages. J. Clean. Prod. 153, 457-464.

Prasad, P., Pagan, R., Kauter, M., Price, N., 2005. Eco-Efficiency for the Dairy Processing Industry.

Pretty, J.N., Ball, A.S., Lang, T., Morison, J.I.L., 2005. Farm costs and food miles: an assessment of the full cost of the UK weekly food basket. Food Policy 30, 1-19.

Realini, C.E., Marcos, B., 2014. Active and intelligent packaging systems for a modern society. Meat Sci. 98, 404-419.

Reckmann, K., Traulsen, I., Krieter, J., 2012. Environmental Impact Assessment Methodology with special emphasis on European pork production. J. Environ. Manag. 107, 102-109.

RedCorn, R., Engelberth, A.S., 2016. Identifying conditions to optimize lactic acic production from food waste co-digested with primary sludge. Biochem. Eng. J. 105, 205-213.

Ribal, J., Fenollosa, M.L., García-Segovia, P., Clemente, G., Escobar, N., Sanjuán, N. 2016a. Designing healthy, climate friendly and affordable school lunches. Int. J. Life Cycle Assess. 21, 631-645.

Ribal, J., Ramírez-Sanz, C., Estruch, V., Clemente, G., Sanjuán, N., 2016b. Organic versus conventional citrus. Impact assessment and variability analysis in the Comunitat Valenciana (Spain). Int. J. Life Cycle Assess. 1-16.

Richardson, N.J., Shepherd, R., Elliman, N.A., 1993. Current attitudes and future influences on meat consumption in the U.K. Appetite 21, 41-51.

Rinaldi, S., Bonamente, E., Scrucca, F., Merico, M.C., Asdrubali, F., Cotana, F., 2016 Water and carbon footprint of wine: methodology review and application to a case study. Sustainability 8, 621.

Romdhana, H., Bonazzi, C., Esteban-Decloux, M., 2016. Computer-aided process engineering for environmental efficiency: industrial drying of biomass. Dry. Technol. 34, 1253-1269.

Roy, P., Orikasa, T., Thammawong, M., Nakamura, N., Xu, Q., Shiina, T., 2012. Life cycle of meats: an opportunity to abate the greenhouse gas emission from meat industry in Japan. J. Environ. Manag. 93, 218-224.

Rugani, B., Vázquez-Rowe, I., Benedetto, G., Benetto, E., 2013. A comprehensive review of carbon footprint analysis as an extended environmental indicator in the wine sector. J. Clean. Prod. 54, 61-77.

Salemdeeb, R., zu Ermgassen, E.K., Kim, M.H., Balmford, A., Al-Tabbaa, A., 2017. Environmental and health impacts of using food waste as animal feed: a comparative analysis of food waste management options. J. Clean. Prod. 140, $871-880$.

Salomone, R., Rupo, D., Saija, G., 2013. Innovative Environmental Management Tools for the Agri-Food Chain. Product-oriented Environmental Management Systems (POEMS). Springer, pp. 3-25. 
Salomone, R., Saija, G., Mondello, G., Giannetto, A., Fasulo, S., Savastano, D., 2017 Environmental impact of food waste bioconversion by insects: application of life cycle assessment to process using Hermetia illucens. J. Clean. Prod. 140, 890-905.

San Martin, D., Ramos, S., Zufia, J., 2016. Valorisation of food waste to produce new raw materials for animal feed. Food Chem. 198, 68-74.

Sanjuán, N., Stoessel, F., Hellweg, S., 2014. Closing data gaps for LCA of food products: estimating the energy demand of food processing. Environ. Sci. Technol. $48,1132-1140$

Santacatalina, J., Soriano, J., Cárcel, J., Garcia-Perez, J., 2016. Influence of air velocity and temperature on ultrasonically assisted low temperature drying of eggplant. Food Bioprod. Process. 100, 282-291.

Saravia-Pinilla, M.H., Daza-Beltrán, C., García-Acosta, G., 2016. A comprehensive approach to environmental and human factors into product/service design and development. A review from an ergoecological perspective. Appl. Ergon. 57, 62-71.

Schlich, E., Fleissner, U., 2005. The ecology of scale: assessment of regional energy turnover and comparison with global food (5 pp). Int. J. Life Cycle Assess. 10, 219-223.

Schmidt, J.H., Weidema, B.P., Brandão, M., 2015. A framework for modelling indirect land use changes in life cycle assessment. J. Clean. Prod. 99, 230-238.

Schneider, K., Hoffmann, I., 2011. Nutrition ecology-a concept for systemic nutrition research and integrative problem solving. Ecol. food Nutr. 50, 1-17.

Schnell, S.M., 2013. Food miles, local eating, and community supported agriculture: putting local food in its place. Agric. Hum. Values 30, 615-628.

Seconda, L., Baudry, J., Allès, B., Hamza, O., Boizot-Szantai, C., Soler, L.-G., Galan, P. Hercberg, S., Lairon, D., Kesse-Guyot, E., 2017. Assessment of the sustainability of the Mediterranean diet combined with organic food consumption: an individual behaviour approach. Nutrients 9, 61 .

Silvenius, F., Grönman, K., Katajajuuri, J.M., Soukka, R., Koivupuro, H.K., Virtanen, Y., 2014. The role of household food waste in comparing environmental impacts of packaging alternatives. Packag. Technol. Sci. 27, 277-292.

Sim, S., Barry, M., Clift, R., Cowell, S.J., 2007. The relative importance of transport in determining an appropriate sustainability strategy for food sourcing. Int. J. Life Cycle Assess. 12, 422.

Skunca, D., Tomasevic, I., Zdolec, N., Kolaj, R., Aleksiev, G., Djekic, I., 2016. Purchase Patterns of Chicken Meat in Southeast Europe 62nd ICoMST. Internationa Congress of Meat Science and Technology "Meat for Global Sustainability", Bangkok, Thailand.

Teixeira, A., Dixon, J., Zahradnik, J., Zinsmeister, G., 1969. Computer optimization of nutrient retention in thermal processing of conduction-heated foods. Food Technol. 23, 845 .

Thomopoulos, R., Croitoru, M., Tamani, N., 2015. Decision support for agri-food chains: a reverse engineering argumentation-based approach. Ecol. Inf. 26 182-191.

Tirado, M.C., Clarke, R., Jaykus, L.A., McQuatters-Gollop, A., Frank, J.M., 2010. Climate change and food safety: a review. Food Res. Int. 43, 1745-1765.

Toepfl, S., Mathys, A., Heinz, V., Knorr, D., 2006. Review: potential of high hydrostatic pressure and pulsed electric fields for energy efficient and environmentally friendly food processing. Food Rev. Int. 22, 405-423.

Uyttendaele, M., Liu, C., Hofstra, N., 2015. Special issue on the impacts of climate change on food safety. Food Res. Int. 68, 1-6.

Valsasina, L., Pizzol, M., Smetana, S., Georget, E., Mathys, A., Heinz, V., 2017. Life cycle assessment of emerging technologies: the case of milk ultra-high pressure homogenisation. J. Clean. Prod. 142, 2209-2217.

van der Werf, H.M., Salou, T., 2015. Economic value as a functional unit for environmental labelling of food and other consumer products. J. Clean. Prod. 94, 394-397.

van Dooren, C., Aiking, H., 2016. Defining a nutritionally healthy, environmentally friendly, and culturally acceptable Low Lands Diet. Int. J. Life Cycle Assess. 21, 688-700.

Van Herzele, A., Dendoncker, N., Acosta-Michlik, L., 2011. Mobilisation capacity for agri-environmental management. J. Environ. Manag. 92, 1023-1032.

van Sluisveld, M.A., Worrell, E., 2013. The paradox of packaging optimization-a characterization of packaging source reduction in The Netherlands. Resour. Conserv. Recycl. 73, 133-142.

Vázquez-Rowe, I., Villanueva-Rey, P., Hospido, A., Moreira, M.T., Feijoo, G., 2014. Life cycle assessment of European pilchard (Sardina pilchardus) consumption. A case study for Galicia (NW Spain). Sci. Total Environ. 475, 48-60.

Vázquez-Rowe, I., Villanueva-Rey, P., Moreira, M.T., Feijoo, G., 2012. Environmental analysis of Ribeiro wine from a timeline perspective: harvest year matters when reporting environmental impacts. J. Environ. Manag. 98, 73-83.

Vermeulen, S.J., Campbell, B.M., Ingram, J.S., 2012. Climate change and food systems. Annu. Rev. Environ. Resour. 37, 195-222.

Wakeland, W., Cholette, S., Venkat, K., 2012. Food Transportation Issues and Reducing Carbon Footprint, Green Technologies in Food Production and Processing. Springer, pp. 211-236.

Walker, C., Berreta, C., Sanjuan, N., Hellweg, S., 2017. Calculating the energy and water Use in food processing and determining the environmental impact of processing on foods. Int. J. Life Cycle Assess. 1-16.

Webb, J., Williams, A.G., Hope, E., Evans, D., Moorhouse, E., 2013. Do foods imported into the UK have a greater environmental impact than the same foods produced within the UK? Int. J. Life Cycle Assess. 18, 1325-1343.

Wezel, A., Bellon, S., Doré, T., Francis, C., Vallod, D., David, C., 2009. Agroecology as a science, a movement and a practice. A review. Agron. Sustain. Dev. 29, 503-515.

Wikström, F., Williams, H., Venkatesh, G., 2016. The influence of packaging attributes on recycling and food waste behaviour - An environmental comparison of two packaging alternatives. J. Clean. Prod. 137, 895-902.

Wikström, F., Williams, H., Verghese, K., Clune, S., 2014. The influence of packaging attributes on consumer behaviour in food-packaging life cycle assessment studies - A neglected topic. J. Clean. Prod. 73, 100-108.

Williams, H., Wikström, F., 2011. Environmental impact of packaging and food losses in a life cycle perspective: a comparative analysis of five food items. J. Clean. Prod. 19, 43-48.

Xu, D., Lin, Z., Gordon, M., Robinson, N., Harder, M., 2016. Perceived key elements of a successful residential food waste sorting program in urban apartments: stakeholder views. J. Clean. Prod. 134, 362-370.

Xu, Z., Sun, D.-W., Zhang, Z., Zhu, Z., 2015. Research developments in methods to reduce carbon footprint of cooking operations: a review. Trends Food Sci. Technol. 44, 49-57.

Young C.E., Kantor, L.S., 1999. Moving Toward the Food Guide Pyramid: Implications for US Agriculture (No. 34071). United States Department of Agriculture, Economic Research Service.

Zhang, X., Vesselinov, V.V., 2016. Integrated modeling approach for optimal management of water, energy and food security nexus. Adv. Water Resour. 